\title{
Revision of the genus Reinmara Schaus, 1928 (Lepidoptera, Mimallonoidea, Mimallonidae) with the descriptions of four new species from South America
}

\author{
Ryan A. St Laurent', Daniel Herbin², Carlos G. C. Mielke \\ I McGuire Center for Lepidoptera and Biodiversity, Florida Museum of Natural History, University of Florida, \\ 3215 Hull Road, Gainesville, FL 32611-2710 USA 2 7, Le Clos de Lutché, F-31380 Garidech, France \\ 3 Caixa Postal 1206, 84.145-000 Carambeí, Paraná, Brazil \\ Corresponding author: Ryan A. St Laurent (rstlaurent@flmnh.ufl.edu) \\ Academic editor: D. Lafontaine | Received 26 February 2017 | Accepted 26 April 2017 | Published 29 May 2017 \\ http://zoobank.org/47DDCEE5-B65C-495D-83DE-0D2016A0F5D2 \\ Citation: St Laurent RA, Herbin D, Mielke CGC (2017) Revision of the genus Reinmara Schaus, 1928 (Lepidoptera, \\ Mimallonoidea, Mimallonidae) with the descriptions of four new species from South America. ZooKeys 677: 97-129. \\ https://doi.org/10.3897/zookeys.677.12435
}

\begin{abstract}
The mimallonid genus Reinmara Schaus, 1928 is revised. The three previously described species, $R$. enthona (Schaus, 1905), $R$. minasa Schaus, 1928, and $R$. wolfei Herbin \& C. Mielke, 2014 are redescribed and the females of each are described and figured for the first time. Additionally, we describe four new species, two Andean: $R$. andensis sp. n. and $R$. occidentalis sp. n., and two Brazilian: $R$. atlantica sp. n. and $R$. ignea sp. n.. The new species $R$. ignea and $R$. atlantica are likely of conservation concern due to their rarity in collections and their apparent endemism to an endangered biome, the Brazilian Atlantic Forest.
\end{abstract}

\section{Keywords}

Bolivia, Brazil, Ecuador, Peru, Taxonomy

\section{Introduction}

The type species of Reinmara Schaus, 1928, $R$. enthona (Schaus, 1905), was originally described in Cicinnus Blanchard, 1852. Cicinnus was, and to some extent, still is a sort of catchall category subsuming many taxa of uncertain phylogenetic position. Later, 
Schaus (1928) established the groundwork for much of the generic classification in current use for the family. In Schaus's work, Reinmara was described to include the Amazonian $R$. enthona and southeastern Brazilian $R$. minasa Schaus, 1928. Like most mimallonid genera described by Schaus, generic characterization was based primarily on wing venation. However, the close association of Reinmara with Trogoptera HerrichSchäffer, [1856], based on male genitalia, was mentioned in this early work.

Since Schaus (1928), one species has been described from the Brazilian Cerrado: R. wolfei Herbin \& C. Mielke, 2014. Therefore, apart from these two works and the species lists of Mimallonidae (Gaede 1931, Becker 1996), very little about this genus has been published. We here revise this genus, figuring both sexes of the three previously described species, the females of all of which were previously unknown. We also recognize and describe four new species, increasing the known diversity of Reinmara to seven species.

\section{Methods}

Dissections were performed as in Lafontaine (2004). Morphological, including genitalia, terminology follows Kristensen (2003). Genitalia and abdomens, when not slide mounted, are preserved in glycerol filled microvials.

Specimens from the following collections were examined:
AMNH American Museum of Natural History, New York, New York, USA
CDH Coll. Daniel Herbin, Garidech, France
CEIOC Entomological Collection of the Oswaldo Cruz Institute, Rio de Janeiro, Rio de Janeiro, Brazil

CGCM Coll. Carlos G. C. Mielke, Curitiba, Paraná, Brazil

CNC Canadian National Collection of Insects, Arachnids and Nematodes, Ottawa, Ontario, Canada

CPC Coll. Philippe Collet, Caen, France

CUIC Cornell University Insect Collection, Ithaca, New York, USA

DZUP Coll. Pe. Jesus S. Moure, Departamento de Zoologia, Universidade Federal do Paraná, Curitiba, Paraná, Brazil

ISEZ The Institute of Systematics and Evolution of Animals of the Polish Academy of Sciences, Kraków, Poland

MGCL McGuire Center for Lepidoptera \& Biodiversity, Gainesville, Florida, USA

MNHN Muséum nationale d'Histoire naturelle de Paris, Paris, France

MNHU Museum für Naturkunde der Humboldt-Universität zu Berlin, Germany

MNRJ Museu Nacional do Rio do Janeiro, Rio de Janeiro, Rio de Janeiro, Brazil

MWM Museum Witt, Munich, Germany

MZSP Museu de Zoologia, Universidade de São Paulo, São Paulo, São Paulo, Brazil

NHMUK Natural History Museum, London, U.K. 
NHRS Entomological Collections, Swedish Museum of Natural History, Stockholm, Sweden

USNM National Museum of Natural History [formerly United States National Museum], Washington D.C., USA

VOB Becker Collection, Camacã, Bahia, Brazil

ZSM Zoologische Staatssammlung München [Munich], Germany

Figures were manipulated with Adobe Photoshop CS4 (Adobe 2008). Male genitalia are figured in natural color with CS4 "auto color" used to improve white backgrounds when necessary. The map was built with SimpleMappr (Shorthouse 2010) and edited with CS4. All geographical coordinates are approximate, and are based on the localities provided on specimen labels when coordinates were not explicitly given. GPS data were acquired with Google Earth.

We used DNA barcoding to help distinguish the similar species Reinmara enthona from $R$. andensis sp. n. Our barcoding protocol used a standardized short sequence of DNA as a species-level character (Hebert et al. 2003, Stoeckle and Hebert 2008), based on the mitochondrial cytochrome c oxidase 1 gene region ("COI"). These "barcodes" were obtained thanks to IBOL (International Barcoding of Life project), and were used in addition to adult habitus and genitalia examination to differentiate the aforementioned morphologically similar species. The Neighbor-joining method (Saitou and Nei 1987) was used to infer the relationships among sampled Reinmara specimens in MEGA6 (Tamura et al. 2013), based on sequences downloaded from and aligned in BOLD (Barcode of Life). 1000 bootstrap replicates were performed and are shown at the nodes of Fig. 7. Evolutionary distances were computed using the Kimura 2-parameter method (Kimura 1980); units of distance reflect the number of base substitutions per site. All codon positions were included. All positions containing gaps and missing data were eliminated. This component of enhanced species delimitation is reflected in the distance tree in Fig. 7.

The symbol $\ddagger$ is used in the text to represent unavailable names in the text (Fletcher and Nye 1982).

\section{Results and discussion}

\section{Reinmara Schaus, 1928: 654.}

Type species. Cicinnus enthona Schaus, 1905; Schaus 1928: 654, by original designation.

Diagnosis. Reinmara can be recognized by the usual contrast between medial and submarginal areas due to diffuse, lighter coloration medially, this coloration, combined with the straight forewing postmedial line, notched tornus, and elongated, slightly falcate forewings (males) distinguish this genus from most other Mimallonidae. The morphologically most similar genus, Trogoptera Herrich-Schäffer, [1856], has more rectangular forewings and often displays more earthen tones (except in $T$. semililacea 
(Dognin, 1916) which is similar in color to some Reinmara but can be recognized by extremely long saccular extensions in the male genitalia). Genitalia of Trogoptera are very similar to those of Reinmara, but the fused gnathos is mesally extended by a singular structure, and is not distally separated as is the same structure in Reinmara. Schaus (1928) noted this difference in his description of Reinmara.

Description. Male. Head: Pale beige to brown, eyes very large, occupying more than two-thirds area of head; antenna pale brown, tan, bipectinate to tip with distal fifth of pectinations much shorter; labial palpus reduced, not extending beyond frons, three segmented, second segment roughly half length of first, third segment reduced, barely visible; vestigial proboscis present. Thorax: Coloration usually as for head but with additional, often pink, shading. Legs: Coloration as for thorax, vestiture thick, long; tibial spurs narrow, very sharp, basal half covered in scales. Forewing dorsum: Forewing length: $12.0-23.5 \mathrm{~mm}$, wingspan: $33-43 \mathrm{~mm}$. Triangular, outer margin concave to varying degrees mesally; tornus usually strongly notched, apex may appear somewhat falcate in species with prominently concave outer margin. Ground color various shades of brown, sparsely scattered with dark brown, tiny petiolate scales usually present. Ante- and medial areas nearly always with pale pink or almost silvery scales throughout, submarginal area generally appearing darker than medial area. Presence of antemedial line variable, dark postmedial line preapical, well defined. Discal mark always present as pale splotch, with darker central region faint or very prominent. Fringe coloration variable. Forewing ventrum: Similar to dorsum but appearing browner overall due to absence of well-defined ante- and medial pink shading, though some pink shading may be present, especially submarginally. Antemedial line absent, postmedial line reduced to traces in all but $R$. ignea sp. n., discal mark more prominent, darker than on forewing dorsum. Hindwing dorsum: Shape more rounded, outer margin convex except for when notch present on anterior margin, patterning as for forewing dorsum, but antemedial line absent, discal mark and postmedial line usually weakly defined. Hindwing ventrum: Following same pattern as forewing ventrum. Frenulum a single bristle. Venation: Typical of Mimallonidae, but Rs3 + Rs4 quite long stalked. Abdomen: Coloration usually as for thorax, but browner, with coppery luster in fresh specimens, fading to pale beige in older material. Vestiture thick, long, distal tip of abdomen with elongated, dark-brown tipped scales. Genitalia: Vinculum ovoid, circumscribing a complex diaphragm with four setae-filled sacks, from a ventral perspective: upper two sacs much smaller and outwardly everted with long outwardly extended setae, lower two sacks larger (bottom right sack the largest of the four), lower sacks not outwardly everted, setae of lower sacks extended outward from within sacks. Uncus simple, broad, truncated to varying degrees distally, appearing beak-like laterally. Gnathos robust, proximally rectangular or rounded, with broad, dual mesal extensions that are fused together near base but bifurcate as fingerlike tips distally. Valves broad, short, rounded apically, sacculus accentuated as slight fold with both blunt and sharp projections near distal most portion of fold, length of sharp projection usually asymmetrical when comparing sacculus of both valves. Juxta partially fused to ventrum of phallus, basally juxta as widened lip where affixed to vinculum. Base 
of relatively small phallus narrower than distal portion, distal half of phallus variable in shape. Vesica very small, globular, with singular, long narrower extension. Female. Head: As for male but slightly broader; antenna dentate with very small pectinations along entire length of flagellum, except in $R$. ignea sp. n. where antenna more similar to that of male, but with smaller pectinations. Thorax: As for male. Legs: As for male. Forewing dorsum: Forewing length: $12-23 \mathrm{~mm}$, wingspan: $27-43 \mathrm{~mm}$. As for male but much broader, margin convex except for just below apex; tornus strongly notched. Coloration and patterning usually as for male, but see $R$. ignea sp. n. Forewing ventrum: Similar to dorsum but appearing browner overall due to absence of well-defined anteand medial pink shading. Antemedial line absent, postmedial line usually reduced to traces, discal mark more prominent, darker than on forewing dorsum. Hindwing dorsum: Similar to forewing dorsum, but notch present on anterior margin, patterning as for forewing dorsum, but antemedial line absent, discal mark and postmedial line usually weakly defined. Hindwing ventrum: Following same pattern as forewing ventrum. Frenulum as multiple bristles. Abdomen: Similar to that of males but more robust overall. Genitalia: Stout, usually robust; tergite VIII forms smooth, posteriorly directed tongue-like extension, VIII heavily sclerotized laterally forming curving plate, which extends outward encircling papillae anales. Apophyses anteriores roughly halflength or equal to that of apophyses posteriores. Lamella ante- and postvaginalis converge as a wide, bowl-like structure. Ductus bursae short, narrow. Corpus bursae small in comparison to robust, heavily sclerotized remainder of genitalia, either bag-like or elongated. Papillae anales broad, rounded, covered in long, fine setae.

Remarks. The genus Reinmara is broadly distributed in South America. Prior to this study very little was known about the genus and females were unknown.

Unlike most genera of Mimallonidae studied by us in recent years, Reinmara have very homogenous male genitalia with only minor differences between externally distinct species (for example $R$. enthona and $R$. minasa), so we relied heavily on external characters, considering habitat specialization and endemism to specific habitats/ biomes as seen in other mimallonid genera, as well as in one case COI barcoding, to differentiate species. We also recognize the close similarity in wing shape and male genitalia morphology between Reinmara and Trogoptera, but maintain them as separate, valid genera pending ongoing phylogenetic work.

\section{Key to species of Reinmara}

1 Size in both sexes moderate (forewing length: $>16 \mathrm{~mm}$ ), forewing antemedial line very faint, if present at all; ventrally, postmedial line on all wings weakly defined, outwardly curved, usually interrupted by wing veins; forewing apex not falcate or if so, weak, blunt. Male genitalia: phallus cylindrical, weakly curved (for example Figs 23c, 24c, 25c).

- $\quad$ Size in both sexes relatively small (12 mm [đ]], 12-16 mm [o] ), forewing antemedial line present, not faint; ventrally postmedial line on all wings essentially as well defined and following the same pattern as on dorsum; forewing 
apex sharply acute, falcate. Male genitalia: phallus thin, strongly curved, and hook-like in shape (Fig. 30c) R. ignea sp. n.

2 Male: Forewing postmedial line not outwardly lined with black suffusion from tornus to apex. Female: Forewing postmedial line not inwardly lined with light pink-gray suffusion, medial area pink suffused 3

- $\quad$ Male: Forewing postmedial line outwardly lined with black suffusion from tornus to apex. Female: Forewing postmedial line inwardly lined with light pink-gray suffusion, medial area largely displaying the light brown ground color, not suffused with pink R. minasa

3 Forewing with deep notch at tornus, eastern slopes of the Andes mountains... 4 Forewing smooth at tornus, notch absent, west of Andes

R. occidentalis sp. $\mathrm{n}$.

4 Phallus mostly cylindrical in shape, not distinctly broadened distally, found in the Amazon rainforest, moderate elevations of the Andes mountains, or from the Brazilian Atlantic Forest .............................................................. 5

- $\quad$ Phallus distinctly broadened distally, endemic to the Cerrado of Brazil and adjacent regions of Bolivia R. wolfei

$5 \quad$ Forewing postmedial line notched toward costa at intersection with Rs4; forewing narrowed apically, slightly falcate, distributed in the Amazon rainforest and Brazilian Atlantic Forest

- $\quad$ Forewing postmedial line not notched toward costa at intersection with Rs4; forewing not noticeably narrowed apically, though if somewhat truncated, submarginal area still broader than any other Reinmara species; endemic to eastern slopes of Andes mountains

$R$. andensis sp. $\mathbf{n}$.

6 Setae-filled diaphragmal sacks of male genitalia well developed, extending into body cavity well beyond vincular ring. Pinkish gray suffusion generally broadly distributed in medial area of forewing. Broadly distributed in the Amazon rainforest R. enthona

- Diaphragmal sacks of male genitalia half the size of those in $R$. enthona, sacks hardly extending into body beyond vinculum. Gray suffusion of medial area restricted to apical confluence of postmedial line with costa. Endemic to Brazilian Atlantic Forest, so far known only from Espírito Santo.

$R$. atlantica sp. $\mathbf{n}$.

\section{Reinmara enthona (Schaus, 1905)}

Figs 1-6, 23, 31, 36

Cicinnus enthona Schaus, 1905: 325-326

Reinmara enthona; Schaus 1928, fig. Oे 88b

Reinmara enthona; Gaede 1931

Reinmara enthona; Becker 1996

Reinmara enthona; Herbin and Mielke 2014, fig. ô 42 
Type material. Holotype, $\widehat{\jmath}$. FRENCH GUIANA: St. Jean, Maroni, F. Guiana/ [Holo]Type, No. 8888, U.S.N.M./ USNM-Mimal: 1059/ Collection Wm Schaus/ Perophora enthona Type Schaus/ St Laurent diss.: 11-1-16:3/ (USNM, examined). Type locality: French Guiana, St. Jean du Maroni.

Additional material examined. (67 $\delta, 3$ + total) SURINAME: $2 \hat{\delta}$, Moengo, Boven Cottica River: 26.V.1927, Cornell Univ. Lot 760, Sub 79, 80, St Laurent diss.: 10-25-15:2 (CUIC). 1 q, Brokopondo, Brownsberg NP, $490 \mathrm{~m}, 04^{\circ} 56^{\prime} 55^{\prime \prime} \mathrm{N}$, $055^{\circ} 10^{\prime} 55^{\prime \prime W}, 23: 55$ h, 28.III.2014, A.J. Hielkema [photographer], At HPL/BL (photo examined, Fig. 6, not collected). FRENCH GUIANA: $2 \pi$, St. Laurent du Maroni, Cr. Naï, PK 13: 27.XII.1991, L. Sénécaux [leg.] (MNHN). 1 Oૈ, Rd. to Kaw, Camp Patawa: 25.III. -7.IV.2008, S. Kohll leg., DNA sample ID BC-Her 2691 (CDH). 1 ô, 19, St. Jean du Maroni, Rd. Apatou, km 15: 27.VII.2011, Ph. Collet leg., UV (CPC). 1 ${ }^{\lambda}$, St. Jean du Maroni: ex. Coll. Wm Schaus, USNM-Mimal:1784 (USNM). 1 , Rd. to Kaw, km $37.5+2,4^{\circ} 33.691$ 'N, 52º8.391'W, 200 m: 30.VII-8.VIII.2003, ex. Coll. M. Laguerre, DNA sample ID BC-Her 2707, genitalia prep. D. Herbin ref. H. 1103 (CDH). 1 Oे, Rd. to Kaw, km 45: 17.VII.1991, F. Bénéluz leg., BMNH(E) 2008-107, NHMUK010247865 (NHMUK). 1 \%, Rd. to Kaw: 16-30.XII.1998, A. Le Flao leg. (MNHN). 1 đ, Rd. to Kaw, km 47: 4.VIII.1991, F. Bénéluz leg., BMNH(E) 2008-107, NHMUK010588025 (NHMUK). 1 đ', Rd. to Patagai, 5²0'34.23"N, 53¹2'47.86"W, 58 m: 3.X.2013, D. Herbin \& O. Felis leg. (CDH). $20^{\wedge}$, Rd. Patagai/Counamama, 5²0'34.23"N, 53¹2'47.86"W, 58 m: 4.XII.2013, D. Herbin leg. (CDH). $10^{\Uparrow}$, Rd. Patagai/Counamama, 5²2'59.51"N, 5312'27.25"W, 49 m: 23.XI.2013, D. Herbin leg. (CDH).

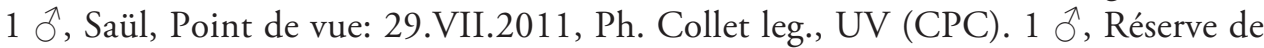
la Trinité, Aya Haute Koursibo: 7.XI.2013, E. Poirier leg., UV (CPC). 1 đ̃, Mont Mitaraka, 300 m: 20.VIII.2015, La Planète Revisitée, MNHN-PNI, Guyane 2015, APA-973-1, Ph. Collet leg. (CPC). 1 ô, Rd. Changement, km 7: 13.VIII.1991, F. Bénéluz leg., BMNH(E) 2008-107, NMHUK010247866 (NHMUK). 1 Oे, Nouragues, Pararé, $4.038113952^{\circ} \mathrm{N}, 52.67309734^{\circ} \mathrm{W}: 23 . V .-5 . V I .2014$, J. Barber, N. Homziack, A.Y. Kawahara, A. Keener \& B. Leavell leg., DNA voucher number LEP-34752 (MGCL, molecular collection, barcoded). $2 \hat{\jmath}$, Rd. Apatou, Layons km 26, $5^{\circ} 14^{\prime} 46.31^{\prime \prime N}, 54^{\circ} 11^{\prime} 07.55^{\prime \prime W}, 126$ m: 1.X.2013, D. Herbin \& O. Felis leg.

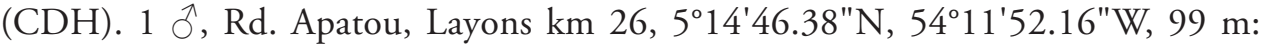
2.X.2013, D. Herbin \& O. Felis leg. (CDH). $1 \mathrm{O}^{\top}$, Plateau des Mines, $5^{\circ} 20^{\prime} 42.59^{\prime \prime N}$, 53\%'31.96"W, 49 m: 4.X.2015, D. Herbin \& M. Laguerre leg. (CDH). 1 §ै, Rd. Coralie, $4^{\circ} 29^{\prime} 07.43^{\prime \prime N}, 52^{\circ} 23^{\prime} 49.40^{\prime \prime} \mathrm{W}, 40$ m: 7.XII.2013, D. Herbin leg. (CDH).

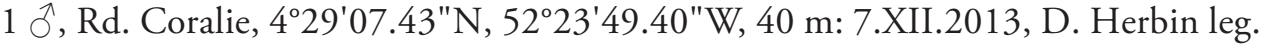
(CDH). 3 đ̂, Rd. Coralie, PK 2: IV.1993, J. Navatte, H. de Toulgoët (MNHN). 1 §, Roura, Rd. Coralie, PK 2: 10.XII.1991, P. Kindl, L. Sénécaux leg., Coll. P. Kindl (MNHN). 1 d , Surroundings of Coralie, rd. dégrad Correze, PK 0.1: 9.XII.1994, P. Kindl leg., Muséum Paris don de Th. Kindl (MNHN). 2 Õ, Roura, Coralie, Rd. of dégrad Corrèz, PK 0.1, P. 10.XII.1991, 16.IV.1994, Kindl leg., Muséum Paris don de Th. Kindl (MNHN). 2 , Rd. de la Montagne de Fer, 5²0'21.17"N, 


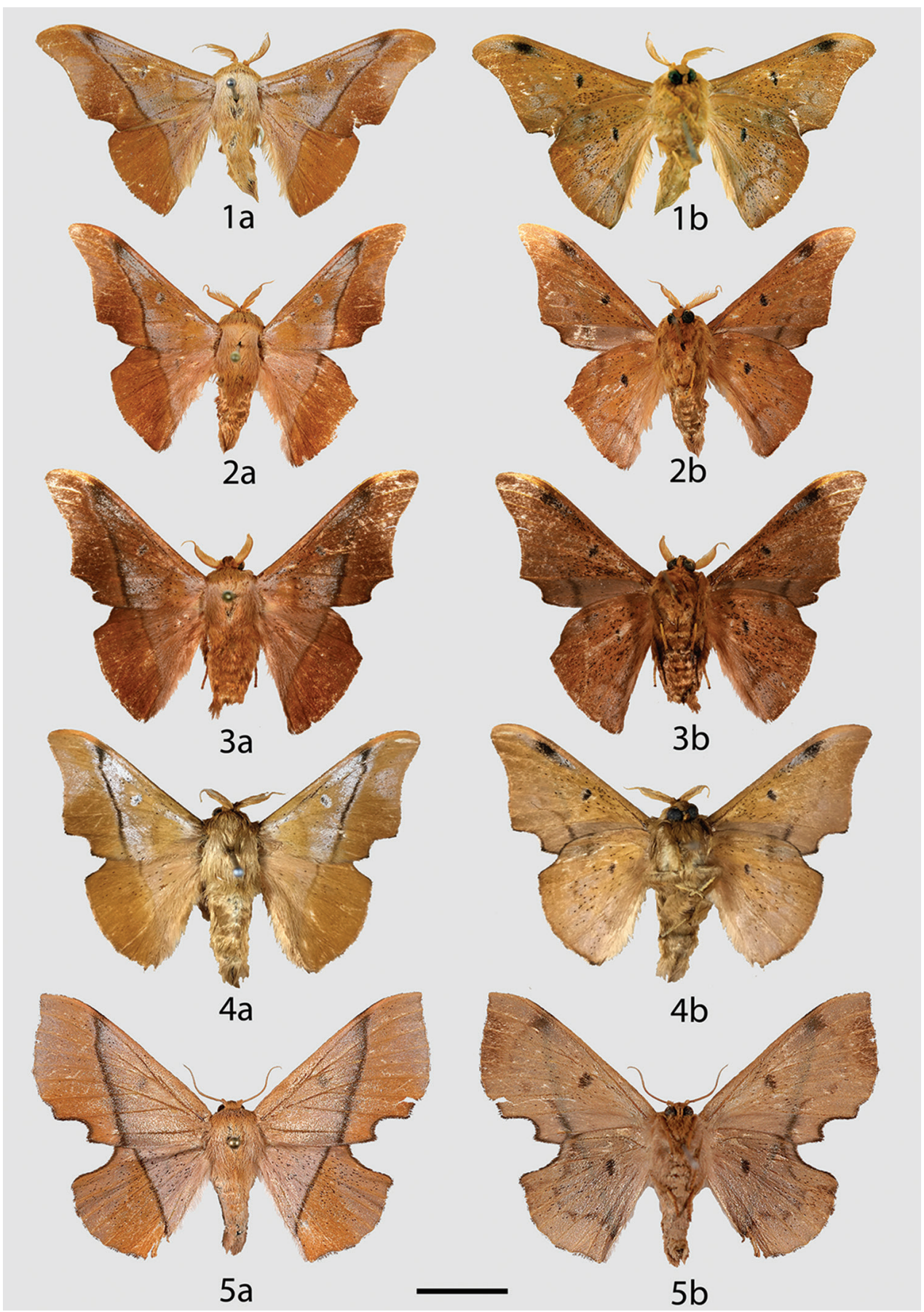

Figures I-5. Reinmara enthona adults, a dorsal b ventral. I Holotype $\hat{\sigma}$, French Guiana, St. Jean du Maroni (USNM) $2 \hat{\jmath}$, French Guiana, Kaw Rd., Camp Patawa (CDH) $3 \hat{\jmath}$, French Guiana, Patagai Rd., 58 m (CDH) 4 đ̆, Brazil, Rondônia, Porto Velho, 180 m (USNM) 5 , French Guiana, Kaw Rd., PK $37.5+2,200 \mathrm{~m}(\mathrm{CDH})$. Scale bar: $1 \mathrm{~cm}$. 
533' $22.10^{\circ} \mathrm{W}, 88$ m: 30.IX.2013, D. Herbin \& O. Felis leg. (CDH). 2 ○, Rd. de Kaw, PK 2.5: 25.III.-17.I.1986, P. Sarry leg., ex. Coll. J. Haxaire (CDH). 1

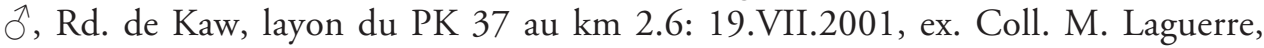
DNA sample ID BC-Her 2708, genitalia prep. D. Herbin ref. H. 653 (CDH). $1 \delta^{\lambda}$, Nouragues research station, $4.098^{\circ} \mathrm{N}, 52.68^{\circ} \mathrm{W}: 9 . I X .2010$, C. Lopez Vaamonde leg., DNA sample ID BIOUG00730-A04 (MNHN). 1 $\hat{\jmath}$, Nouragues, Inselberg Camp, Heliport drop zone, $4.088^{\circ} \mathrm{N}, 52.681^{\circ} \mathrm{W}$ : 1.II.2011, M. Smith \& R. Rougerie leg., DNA sample ID NS-RR0769 (MNHN). 1 ô, Orapu, Crique Grillon: 13.IV.1994, P. Kindl leg. (MNHN). GUYANA: 1 ô, Amazon-Courantyne divide, head of Oronoque River: 1937, H. Beddington [leg.], B.M. 1937-588 (NHMUK). 1 đ, Potaro: II.1908, S.M. Klages [leg.], Rothschild Bequest BM 19391 (NHMUK). VENEZUELA: Amazonas: $1 \overbrace{}^{\lambda}$, Río Mavaca, $2^{\circ} 2^{\prime} \mathrm{N}, 65^{\circ} 6^{\prime} \mathrm{W}, 150$ m: 16-27.III.1989, David Grimaldi leg., Exp. Phipps-Fudeci (AMNH). BRAZIL: Amazonas: $4 \hat{\delta}$, Reserva Ducke, km 26, Hwy. Manaus-Itacoatiara: 16.IV.1972, 20.IV.1972, 15.V.1972, 21.V.1972, E.G., I. \& E.A. Munroe [leg.], St Laurent diss.: 5-18-16:1 (CNC). 1 §ै, Fonte Boa, Upper Amazons: VI.1906, S.M. Klages [leg.], Rothschild Bequest, BM 1939-1, NHMUK010354559, St Laurent diss.: 11-1-16:8 (NHMUK). 1 गे, Manaus, Uypiranga, m/d [right margin] of Rio Negro: X.1941, Parko leg., N. 10.822 I. Oswaldo Cruz, USNM-Mimal: 2404 (USNM). Pará: 1

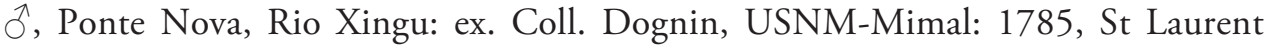
diss.: 11-1-16:4 (USNM). 1 ðૈ, Belém, 20 m: I.1984, V.O. Becker leg., ex. Coll. Becker 46466, USNM-Mimal: 2211 (USNM). 1 § , No specific locality: A.M. Moss [leg.], Rothschild Bequest, BM 1939-1 (NHMUK). Rondônia: 8 Oे, Porto Velho, 180 m: 24-30.IV.1989, V.O. Becker leg., ex. Coll. Becker 61968, USNM-Mimal: 2200-2207, St Laurent diss.: 11-1-16:5, 11-16:10 (USNM). 1 đै, Vilhena, 600 m: 9.XII.1997, V.O. Becker leg., ex. Coll. Becker 111449, USNM-Mimal: 2029, St Laurent diss.: 11-16:16 (USNM). PERU: Madre de Dios: 1 ô, Upper Río Madre de Dios, Manu Park, 30-40 km S Salvación, 300 m: VIII.1998 (MWM). 1 đૈ, Río Madre de Diós, E. de Salvación, 300 m: VII.1998, don de Claude Lemaire

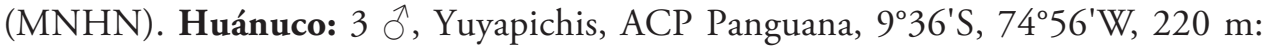

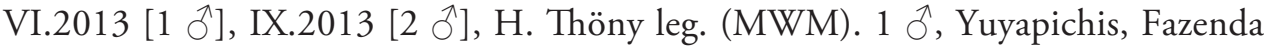

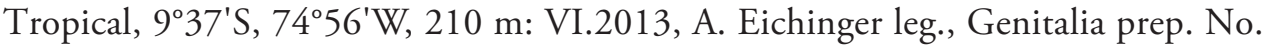
29.220 MWM (MWM).

Diagnosis. Reinmara enthona, the type species of the genus Reinmara, is recognizable by the extensive suffusion of pinkish gray in the medial area. It is very similar to the following two species, but of the three species, $R$. enthona has the most extensive rosy medial suffusion, and a narrow submarginal area with quite falcate forewings (like $R$. atlantica sp. n., but unlike $R$. andensis sp. n.). The genitalia are intermediate in size between those of $R$. andensis and $R$. atlantica. The large diaphragmal sacks of $R$. enthona are similar to, but still smaller than those of $R$. andensis, whereas the same sacks of $R$. atlantica are about $50 \%$ smaller.

Description. Male. Head: As for genus, but light brown in color. Thorax: Coloration as for head. Legs: Coloration as for thorax, vestiture thick, long. Forewing dorsum: 


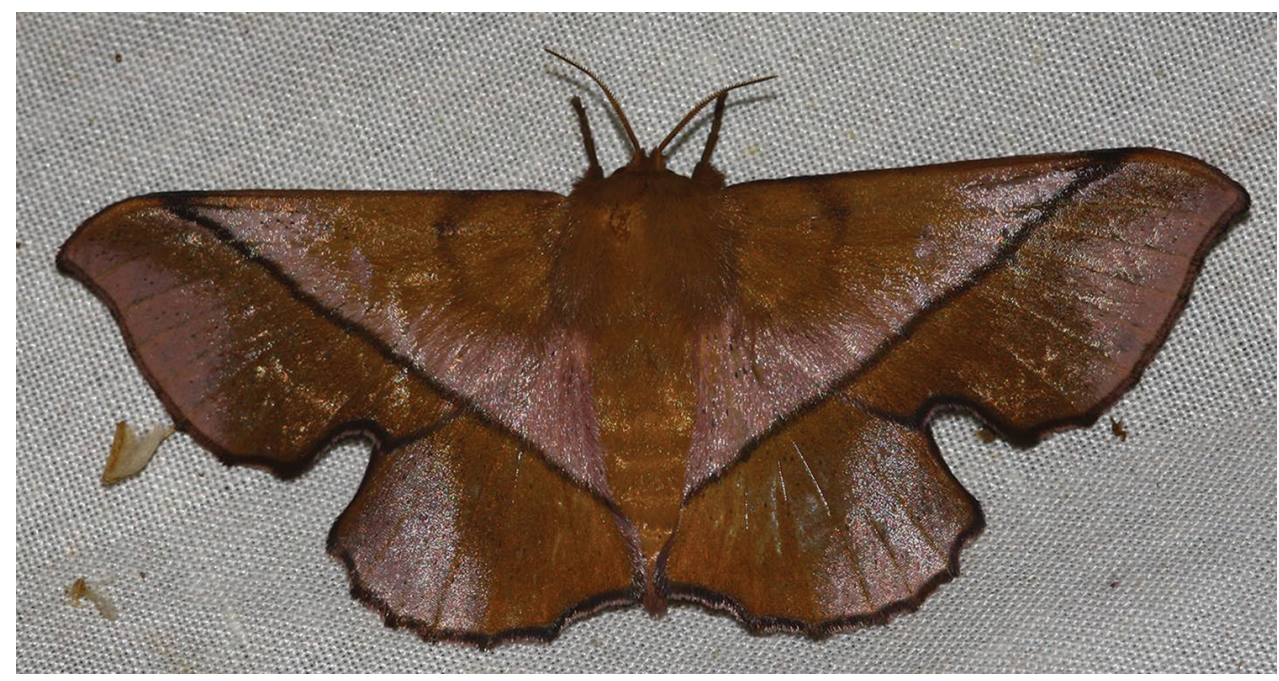

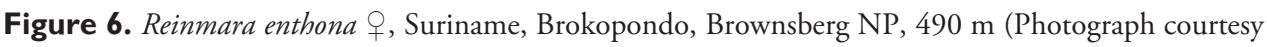
of A.J. Hielkema, used with permission).

Forewing length: $16-22 \mathrm{~mm}$, avg.: $19 \mathrm{~mm}$, wingspan: $36-43 \mathrm{~mm}, \mathrm{n}=16$. Triangular, outer margin concave below apex; tornus notched, apex usually somewhat falcate. Ground color light brown to rich chocolate brown, very sparsely scattered with tiny, dark-brown, petiolate scales. Ante- and medial areas lighter brown than darker brown submarginal area, though in some specimens medial area may be very dark brown with less suffusion of grayish pink, lighter pinkish-gray scales present throughout medial area, including near costa on outer edge of postmedial line. Antemedial line almost nonexistent. Discal spot dark ovoid mark, surrounded by pale-gray scales, darker central area variable in expanse. Fringe coloration lighter brown than wing margin. Forewing ventrum: Similar to dorsum but more homogenously brown overall with very obvious black splotch at costa where postmedial line meets it, covering of dark petiolate scales may be much more extensive than on dorsum. Antemedial line absent, postmedial line reduced to traces. Hindwing dorsum: Notch on anterior margin weak, patterning as for forewing dorsum, but antemedial line absent, discal mark and postmedial line weakly defined. Hindwing ventrum: Following same pattern as forewing ventrum but traces of postmedial line outwardly bent mesally. Abdomen: Coloration as for thorax. Genitalia: (Fig. 23) n=10. Typical of genus, uncus triangular but truncated distally. Gnathos with relatively short fingerlike tips of paired extensions. Valves broad, phallus somewhat conical, curved, distally quite broadened, but variable in width. Female. Head: As for male but slightly broader; antenna dentate with very small pectinations along entire length of flagellum. Thorax: As for male. Legs: As for male. Forewing dorsum: Forewing length: $23 \mathrm{~mm}$, wingspan: $43 \mathrm{~mm}$, $\mathrm{n}=1$. As for male but much broader, margin convex except for just below apex; tornus strongly notched. Coloration and patterning usually as for male but medial area more 


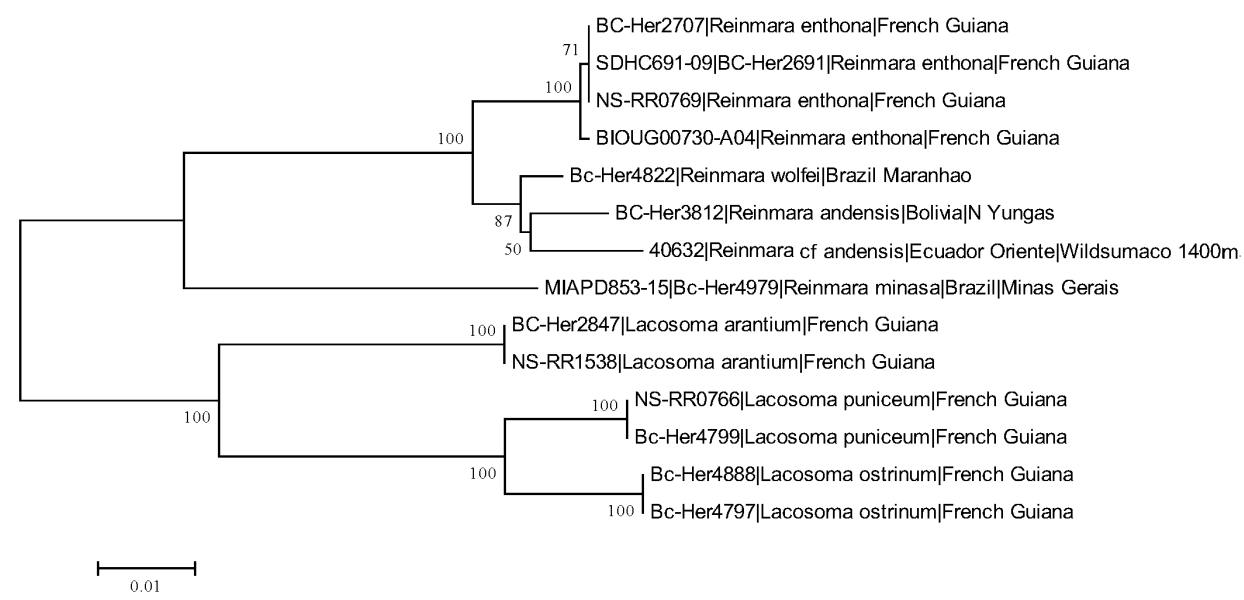

Figure 7. Phylogenetic tree built with neighbor-joining method in MEGA6 showing relationships among Reinmara, with Lacosoma Grote, 1864 as the outgroup. See remarks section for $R$. andensis regarding noted issues with this analysis.

uniformly pink, discal mark nearly absent. Forewing ventrum: Similar to dorsum but appearing browner overall due to absence of well-defined ante- and medial pink shading. Antemedial line absent, postmedial line reduced to traces, discal mark more prominent, darker than on forewing dorsum. Hindwing dorsum: Similar to forewing dorsum, but notch present on anterior margin, patterning as for forewing dorsum, but antemedial line absent. Hindwing ventrum: Following same pattern as forewing ventrum. Abdomen: Similar to that of male but more robust overall. Genitalia: (Fig. 31) $n=1$. Stout, robust; tergite of VIII forms elongated, posteriorly directed tonguelike overhang, VIII heavily sclerotized laterally forming curving plate below papillae anales. Apophyses anteriores roughly half-length of apophyses posteriores. Lamella ante- and postvaginalis converge as a wide, bowl-like structure covered in setae. Ductus bursae short, narrow. Balloon-like corpus bursae rather small in comparison to robust, heavily sclerotized remainder of genitalia. Papillae anales broad, apical pronounced, covered in long, fine setae.

Distribution (Fig. 36). This species is broadly distributed throughout the Amazon rainforest at lower elevations. There are records from Venezuela, Suriname, Guyana, French Guiana, Brazil, and Peru.

Remarks. Considering the expansive distribution of $R$. enthona, this name potentially includes several cryptic species. This section of the genus Reinmara warrants future investigation, especially on the lower and moderate elevations of the eastern Andes Mountains. We call attention to specimens from moderate elevations in Peru (MWM) and those from about $1400 \mathrm{~m}$ in Ecuador (MGCL) which could be $R$. enthona, $R$. andensis sp. n., or additional taxa. See remarks of $R$. andensis sp. n. for further discussion on this matter. 


\section{Reinmara atlantica sp. $\mathbf{n}$.}

http://zoobank.org/4408352E-9363-4329-AADD-EA7E0C62DD5C

Figs 8, 24, 36

Type material. Holotype, Ô. BRAZIL: Espírito Santo: BRASIL: ES, Linhares. 40 m, 05-09.iv.1992, V.O.Becker Col/ Col. BECKER 82019/ USNM-Mimal: 2208/ St Laurent diss.: 11-1-16:6/ HOLOTYPE ô Reinmara atlantica St Laurent, Herbin, \& C. Mielke, 2017 [handwritten red label]/ (ex-USNM, DZUP). Type locality: Brazil, Espírito Santo, Linhares.

Paratypes. (3 0 total) BRAZIL: Espírito Santo: $2 \hat{\jmath}$, same data and Becker number as the holotype, USNM-Mimal: 2209-2210, St Laurent diss.: 11-1-16:7 (USNM). $1 \hat{\partial}$, same data and Becker number as holotype (VOB).

Diagnosis. Reinmara atlantica is very similar to $R$. enthona but is darker brown, usually slightly smaller, and has narrower forewings. Also, the light gray medial suffusions are mostly restricted to area along the postmedial line, especially near the costa, and are not present throughout the medial region as in $R$. enthona. The postmedial line is slightly angled toward the costa at Rs4 in $R$. atlantica, not interrupted there in $R$. enthona. The genitalia can be recognized by the narrower valves and smaller gnathos extensions relative to the whole of the genitalia. Perhaps the most reliable character differentiating these two species is the reduced size of all four diaphragmal sacs, especially noticeable in the lower right sac which is very reduced in comparison to that of $R$. enthona, and hardly extends inward toward the body cavity, whereas this huge sac in $R$. enthona extends well into the body cavity past the vincular ring.

Description. Male. Head: As for genus, but light brown in color. Thorax: Coloration as for head. Legs: Coloration as for thorax, vestiture thick, long. Forewing dorsum: Forewing length: 19-20 mm, avg.: $19.7 \mathrm{~mm}$, wingspan: 35-36 mm, $\mathrm{n}=3$. Triangular, outer margin concave below apex; tornus notched, apex somewhat falcate. Ground color rich brown, very sparsely scattered with tiny, dark-brown, petiolate scales. Anteand medial areas lighter brown than darker brown submarginal area, lighter gray scales present near costa on both sides of postmedial line, but more expansive on inner side with narrow strip of suffusion scales along postmedial line, fading before anterior wing margin, small patch of light-gray scales also present in antemedial area. Antemedial line almost nonexistent. Discal spot dark ovoid mark, surrounded by pale-gray scales. Fringe coloration lighter with nearly white trailing edge. Forewing ventrum: Similar to dorsum but more homogenously brown overall with very obvious black splotch at costa where postmedial line meets it. Antemedial line absent, postmedial reduced to traces. Hindwing dorsum: Notch on anterior margin weak, patterning as for forewing dorsum, but antemedial line absent, discal mark and postmedial line weakly defined. Hindwing ventrum: Following same pattern as forewing ventrum but traces of postmedial line outwardly bent mesally. Abdomen: Coloration as for thorax. Genitalia: (Fig. 24) n=2. Typical of genus, very similar to that of $R$. enthona but gnathos size reduced relative to whole of genitalia, diaphragm sacks much smaller overall especially lower right sac, which barely extends into body cavity past vincular ring, valves slightly narrower. Female. Unknown. 


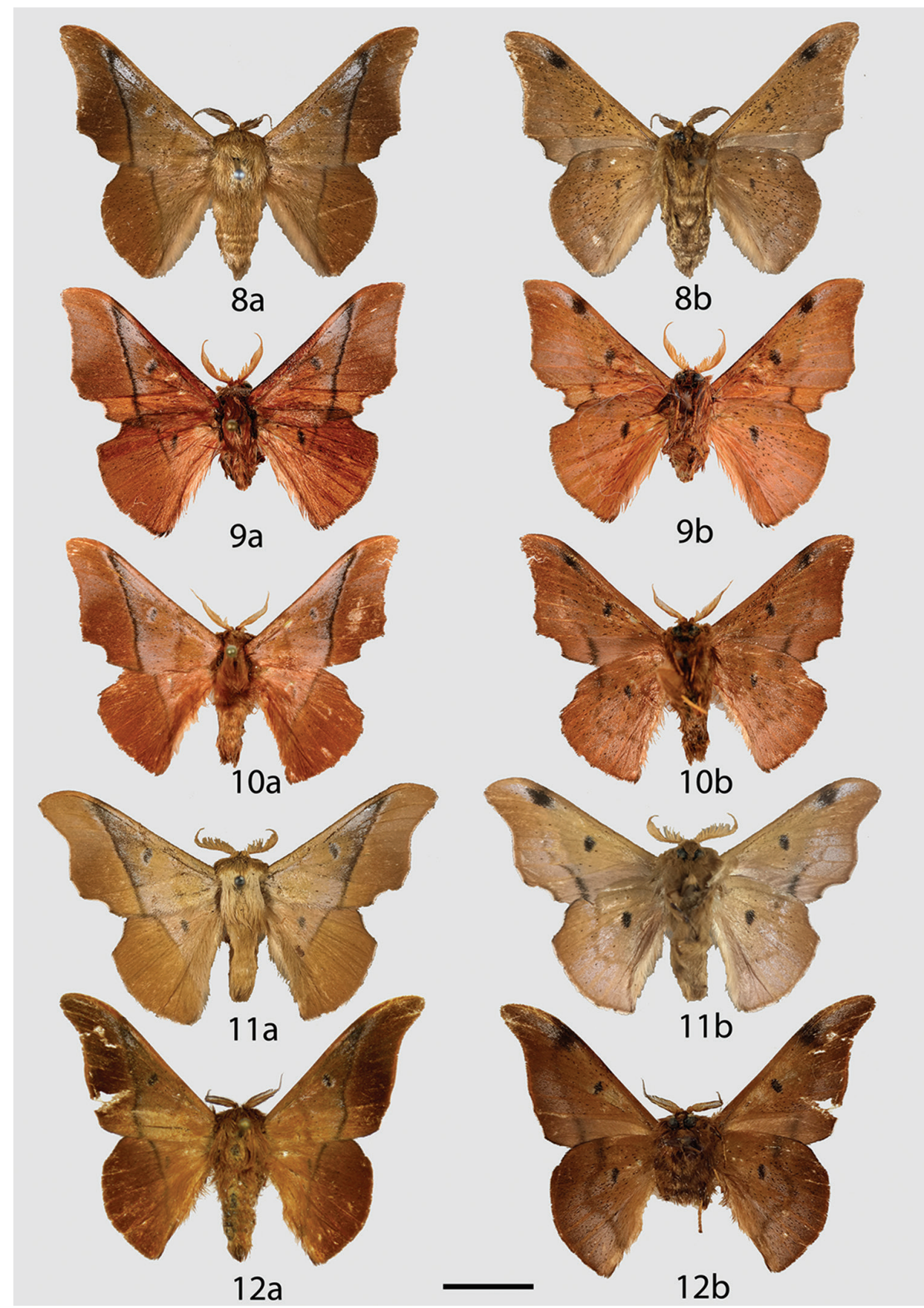

Figures 8-12. Reinmara adults, a dorsal b ventral. 8 R. atlantica Holotype $\widehat{O}$, Brazil, Espírito Santo, Linhares, $40 \mathrm{~m}$ (DZUP) $9 R$. andensis Holotype $\widehat{\partial}$, Bolivia, N. Yungas, 1000-1800 m (MNHN) $10 R$. andensis Paratype $\hat{\sigma}$, Locality as for Fig. $9(\mathrm{CDH})$ II $R$. andensis Paratype $\hat{\sigma}$, Peru, Puno, Oroya, Río Inambari, $3100 \mathrm{ft}$ (NHMUK) I 2 R. occidentalis Holotype $\widehat{\partial}$, Ecuador, El Oro, 10 km NW Piñas, $750 \mathrm{~m}$ (MWM). Scale bar: $1 \mathrm{~cm}$. 
Distribution (Fig. 36). Reinmara atlantica is known only from the type locality in Espírito Santo, Brazil near sea level in the Atlantic Forest.

Etymology. This new species is named for the type locality, which is situated very near to the Atlantic coast of Brazil.

Remarks. Despite an abundance of Mimallonidae material from the Brazilian Atlantic Forest in collections visited during the course of this research (see list in Methods), the four specimens from Linhares were the only $R$. atlantica material located from this hyperdiverse biome. This species may be much more restricted within this biome than other species in the family that are also endemic to the Brazilian Atlantic Forest.

\section{Reinmara andensis sp. $\mathbf{n}$.}

http://zoobank.org/0AFC5C82-6BB5-47FB-B86F-76B76B06259C Figs 9-11, 25, 36

Type material. Holotype, $\curvearrowright$. BOLIVIA: BOLIVIE, N. Yungas, 1000-1800 m, Oct,nov,Dec,2008, Leg. local collector for R. Marx, Coll. D. Herbin/ genitalia prep. D. Herbin ref H. 1134/ HOLOTYPE male Reinmara andensis St Laurent, Herbin, \& C. Mielke, 2017 [handwritten red label]/ (MNHN). Type locality: Bolivia, northern Yungas [no specific locality provided on data label].

Paratypes. (9 $\hat{\sigma}$ total) BOLIVIA: $1 \hat{\jmath}$, same data as for holotype (CDH). La Paz: $1 \overbrace{}^{\AA}$, Nor [North] Yungas, Road Caranavi-Coroico, ca. $100 \mathrm{~km} \mathrm{NE} \mathrm{La} \mathrm{Paz,} \mathrm{ca.} 16.2^{\circ} \mathrm{S}$, 67.6 W, 1000-1800 m: V-VI.2009, R. Brechlin \& F. Meister leg. (MWM). 1 ô, Río Songo [recte Río Zongo], 750 m: ex-Coll. Fassl, NHRS-TOBI 1951 (NHRS). PERU: Puno: 1 đ̃, Santo Domingo, Carabaya, 6000 ft: I.1902, wet season, Ockenden [leg.], Rothschild Bequest, BM 1939-1, NHMUK01354562 (NHMUK). 1 ๙, Locality as for previous but: VI.1902, dry season, NHMUK 010318284 (NHMUK). 2 đ̊, La Oroya [Oroya], Río Inambari, 3100 ft: III.1905, XI-XII.1905, wet season, G. Ockenden [leg.], Rothschild Bequest, BM 1939-1, NHMUK010354561, St Laurent diss.: 11-1-16:9 (NHMUK). 2 गे, Locality and collector as for previous but: $3000 \mathrm{ft}$, V.1905, Ex-Coll. Oberthür, Brit. Mus. 1927-3, NHMUK010354560 (NHMUK).

Specimens of uncertain identity hereby excluded from the type series. ECUADOR: Napo: 1 đ, 1 q, Wildsumaco Biol. Stat., E slope Andes Mtns, 040'17.2"S, 77³5'55.1"W, -1400 m: 1-14.VIII.2016, Kawahara + Barber Labs et al. leg., DNA voucher numbers LEP-40632, 42829 (MGCL, molecular collection, barcoded). PERU: San Martín: 1 đ̄, Mina de Sal, 1400 m: V.2007, Rainer Marx leg., Genitalia prep. No. 29.219 MWM (MWM). Huánuco: 1 đ̋, Leoncio Prado, La Divisoria, 1600 m: 20.VI.1982, Charles F. Zeiger [leg.] (MGCL).

Diagnosis. Reinmara andensis is similar to $R$. enthona but larger, with broader wings and broader submarginal areas, which are more uniformly light brown. Medially the light gray scaling is reduced in comparison with $R$. enthona. The genitalia are very similar to those of $R$. enthona, but are overall somewhat larger, the gnathos extensions are shorter and phallus more tubular with a more protruding ventral distal lip in 
comparison with $R$. enthona. The lower right diaphragm sac is larger and more ovoid in shape in $R$. andensis, in $R$. enthona it is smaller and more spherical.

Description. Male. Head: As for genus, but light brown in color. Thorax: Coloration as for head. Legs: Coloration as for thorax, vestiture thick, long. Forewing dorsum: Forewing length: 18.5-20.0 mm, avg.: $19.2 \mathrm{~mm}$, wingspan: $37-40 \mathrm{~mm}, \mathrm{n}=5$. Triangular, margin slightly concave below apex; tornus notched, apex hardly falcate. Ground color light orange-brown, very sparsely scattered with tiny, dark brown, petiolate scales. Ante- and medial areas appearing lighter brown than more uniformly orange-brown submarginal area due to suffusion of lighter gray scales medially, especially near costa and on inner side of postmedial line, in some specimens medial area may be very dark brown with less suffusion of grayish pink. Antemedial line almost nonexistent. Discal mark pale gray, ovoid, variously darkened at center. Fringe coloration lighter than wing margin with nearly white trailing edge. Forewing ventrum: Similar to dorsum but more homogenously brown overall due to reduction in paler gray shading. Antemedial line absent, postmedial line reduced to traces. Hindwing dorsum: Notch on anterior margin weak, patterning as for forewing dorsum, but antemedial line absent, discal mark and postmedial line weakly defined. Hindwing ventrum: Following same pattern as forewing ventrum but traces of postmedial line outwardly bent mesally. Abdomen: Coloration as for thorax. Genitalia: (Fig. 25) n=4. Typical of genus, very similar to that of $R$. enthona but overall larger structures, with shorter but more robust gnathos extensions and a more tubular phallus with more prominent ventral distal lip. Female. Unknown [putative female from Wildsumaco, Napo, Ecuador does not differ from female $R$. enthona].

Distribution (Fig. 36). Reinmara andensis is an Andean species present in southeastern Peru in the Puno region, as well as northwestern Bolivia. Other records from north central Peru in San Martín and Huánuco as well as eastern Ecuador may represent this or additional cryptic Andean taxa.

Etymology. This new species is named for its Andean distribution.

Remarks. Additional material from MWM and MGCL from other localities in Peru besides those from the Puno region need verification due to the unreliability of the collector and/or unclear collecting data. We anticipate that this new species is more broadly distributed, but considering the close similarity to $R$. enthona and unavailability of recently collected Peruvian material, we restrict the type series of this species to include only those from northwestern Bolivia and adjacent southeast Peru. Although $R$. andensis is endemic to the eastern slopes of the Andes, it appears to be sympatric with $R$. enthona at the lower elevations in the inhabited range of $R$. andensis.

Due to the barcoding results (Fig. 7) and biogeography placing an Ecuadorian specimen (Lep-40632) closer to $R$. andensis, we have included specimens from this location under additional examined material for $R$. andensis, though they are excluded from the type series pending additional information. Furthermore, these barcoding results are not clear in that $R$. wolfei (Bc-Her4822) is nested within the clade including $R$. andensis and the Ecuadorian $R$. cf andensis, with low bootstrap support. Morphology certainly suggests that $R$. enthona and $R$. andensis are more similar than the rather 
unique, $R$. wolfei. Additional molecular and morphological data will be required to fully elucidate the relationships within Reinmara. We do not consider single genes, particularly COI, to offer significant phylogenetic signal, especially considering recent work refuting species delimitation based on genetic evidence alone (Sukumaran and Knowles 2017), thus we include the tree in Fig. 7 merely as additional evidence differentiating the Amazonian $R$. enthona from the externally similar Andean $R$. andensis.

In the NHMUK, the Peruvian specimens were collected both during the "dry season" and "wet season" with those specimens from the dry season being smaller overall than those from the wet season. No significant genitalia differences were noted between these sets of specimens however. Reinmara andensis is generally larger than $R$. enthona but dry season $R$. andensis are much closer in size to those of $R$. enthona.

\section{Reinmara occidentalis sp. $\mathbf{n}$.}

http://zoobank.org/2A610073-44B4-48BD-BF4A-F0808DA6530B

Figs 12, 26, 27, 36

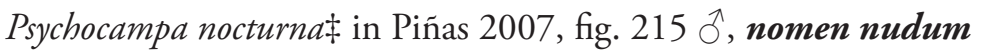

Type material. Holotype, $\widehat{\jmath}$. ECUADOR: El Oro: ECUADOR, El Oro prov. $10 \mathrm{~km}$ NW PIÑAS, 338'51"S, 7945'52"W, 12.04.2012; H=750 m, leg. R. Brechlin \& V. Sinyaev, Museum Witt/ Genitalpräparat Heterocera Nr. 29.218 Musuem WITT München/ HOLOTYPE male Reinmara occidentalis St Laurent, Herbin, \& C. Mielke, 2017 [handwritten red label]/ (MWM). Type locality: Ecuador, El Oro, $10 \mathrm{~km} \mathrm{NW}$ of Piñas.

Paratype. ECUADOR: El Oro: $1 \hat{\gamma}$, Road Piñas-Saracay, $3^{\circ} 39^{\prime} 52^{\prime \prime S}, 79^{\circ} 45^{\prime} 26^{\prime \prime} \mathrm{W}$, 800 m: 6.XII.2012, Sinyaev \& Romanov, expedition Ron Brechlin leg., genitalia prep. 30.813 (MWM).

Diagnosis. Reinmara occidentalis is one of most obscurely colored species in the genus. This new species is recognizable by the lack of a well-defined notch on the forewing tornus, which is instead smooth, and by the dark brown submarginal coloration with an almost complete absence of gray/pink shading in the medial region. On the ventral surface of the wings, the postmedial line is more continuous and less intermittently notched than in $R$. enthona, $R$. atlantica, or $R$. andensis. The male genitalia are also unique in this species because the gnathos extensions are quite long and deeply divergent, and the phallus is somewhat twisted, noticeably bent, and broadened distally unlike any other in the genus. This species is so far the only Reinmara known from the western slopes of the Andes.

Description. Male. Head: As for genus, but dark brown in color. Thorax: Coloration as for head but slightly lighter brown. Legs: Coloration as for thorax, vestiture thick, long. Forewing dorsum: Forewing length: $22.5-23.5 \mathrm{~mm}$, avg.: $23 \mathrm{~mm}$, wingspan: $40-42 \mathrm{~mm}, \mathrm{n}=2$. Triangular, outer margin weakly concave below apex; tornus smooth, unnotched, apex somewhat falcate. Ground color brown, sparsely scattered with dark brown, tiny petiolate scales. Ante- and medial areas lighter brown than darker, chocolate brown submarginal area, lighter gray scales present near costa on 
both sides of postmedial line. Antemedial line light brown but darker than surrounding area, wavy. Discal mark ovoid, surrounded by pale gray scales. Fringe coloration lighter brown than submarginal area. Forewing ventrum: Similar to dorsum but more homogenously brown overall, pale gray shading more evident near apex and submarginally. Antemedial line absent, postmedial line as on dorsum but fainter. Hindwing dorsum: Anterior margin without notch, but edge flatter than mesal wing margin. Patterning as for forewing dorsum, but antemedial line absent, discal mark and postmedial line weakly defined. Hindwing ventrum: Following same pattern as forewing ventrum but postmedial line outwardly bent mesally. Abdomen: Coloration as for thorax. Genitalia: (Fig. 26, 27) n=2. Typical of genus, differing in the more robust gnathos mesal extensions with particularly elongated fingerlike tips, phallus twisted, bent mesally, and distally broadened. Female. Unknown.

Distribution (Fig. 36). Reinmara occidentalis is known from only two locations separated by a little over $2 \mathrm{~km}$ in the El Oro province of western Ecuador, on the western slopes of the Andes mountains from $750-800 \mathrm{~m}$ in elevation.

Etymology. This new species is named for the western (occidentalis Latin) Andean distribution.

Remarks. We are only aware of two specimens of this new species. Although data is still lacking in regards to the extent of the distribution of $R$. occidentalis, the distribution as well as the external morphology of this species are quite distinct from all others in the genus.

A specimen that may represent this new species was figured (fig. 215) in the plates of Piñas (2007) with the unavailable name Psychocampa nocturna $\ddagger$ Piñas assigned by the author. As per information available in Thöny and Piñas $(2015,2017)$, all names proposed by Piñas in his works "Mariposas del Ecuador" are unavailable and must be regarded as nomina nuda since they do not satisfy ICZN requirements for taxonomically available name (e. g. no description is provided). Thus, we above treat this name as nomen nudum. While the specimen figured in Piñas (2007) closely resembles $R$. occidentalis by the obscured coloration, there is a weak notch present at the tornus of the forewings, thus we cannot say for certain if it is indeed this species. Furthermore, locality information is not available, so we are not able to verify if the locality for this particular specimen satisfies our understanding of the west Andean distribution of $R$. occidentalis. The listed wingspan of $44 \mathrm{~mm}$ is greater than that of either specimen that we have examined.

\section{Reinmara wolfei Herbin \& C. Mielke, 2014}

Figs 13-16, 28, 32, 36

Reinmara wolfei Herbin and Mielke, 2014: 144, figs ô 40, 41, 43

Type material. Holotype, $\widehat{\jmath}$. BRAZIL: Maranháo: holotype, Reinmara wolfei HERBIN \& MIELKE det./ Brésil, Maranhão, Feira Nova do Maranhão, Retiro, 480 m, 

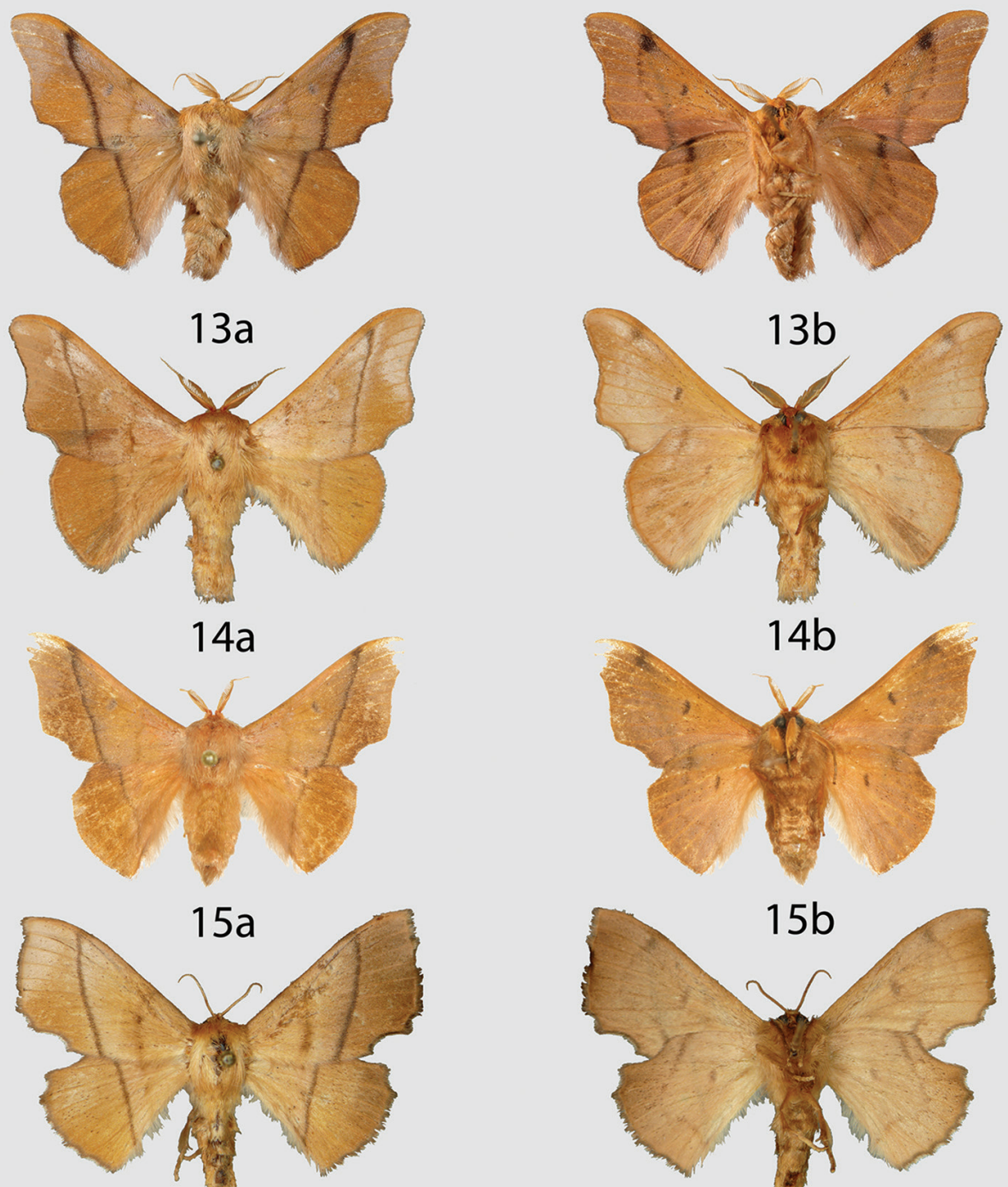

$16 a$

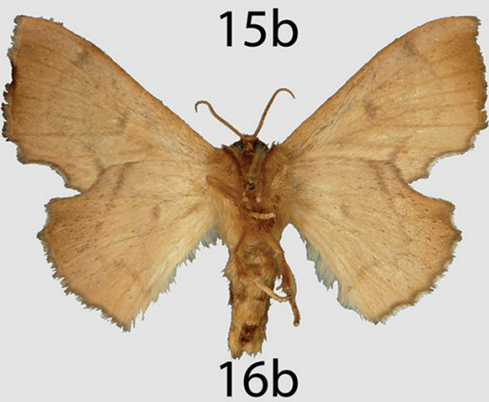

Figures 13-16. Reinmara wolfei adults, a dorsal b ventral. I 3 Holotype $\lesssim$, Brazil, Maranhão, Feira Nova do Maranháo, $480 \mathrm{~m}$ [image originally published by Antenor, reused with permission] (DZUP) 14 đิ, Brazil, Distrito Federal, Planaltina, $1000 \mathrm{~m}$ (CPAC) 15 ô, Brazil, Mato Grasso, $60 \mathrm{~km} \mathrm{~S}$. of Poconé, Pantanal, $100 \mathrm{~m}$ (USNM) 16 \%, Locality as for Fig. 14 (CPAC). Scale bar: $1 \mathrm{~cm}$.

24/31-XII-2011, 0700'31"S, 46²6'41"W, C. MIELKE leg./ DZ 15.713/ Genitalia prep. D. Herbin ref. H 953/ (DZUP, examined). Type locality: Brazil, MA, Feira Nova do Maranhão.

Additional material examined. ( $7 \hat{\sigma}, 4 q$ total) BRAZIL: Maranhão: $1 \hat{\sigma}$, Balsas,

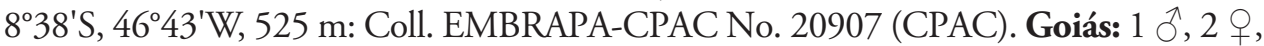




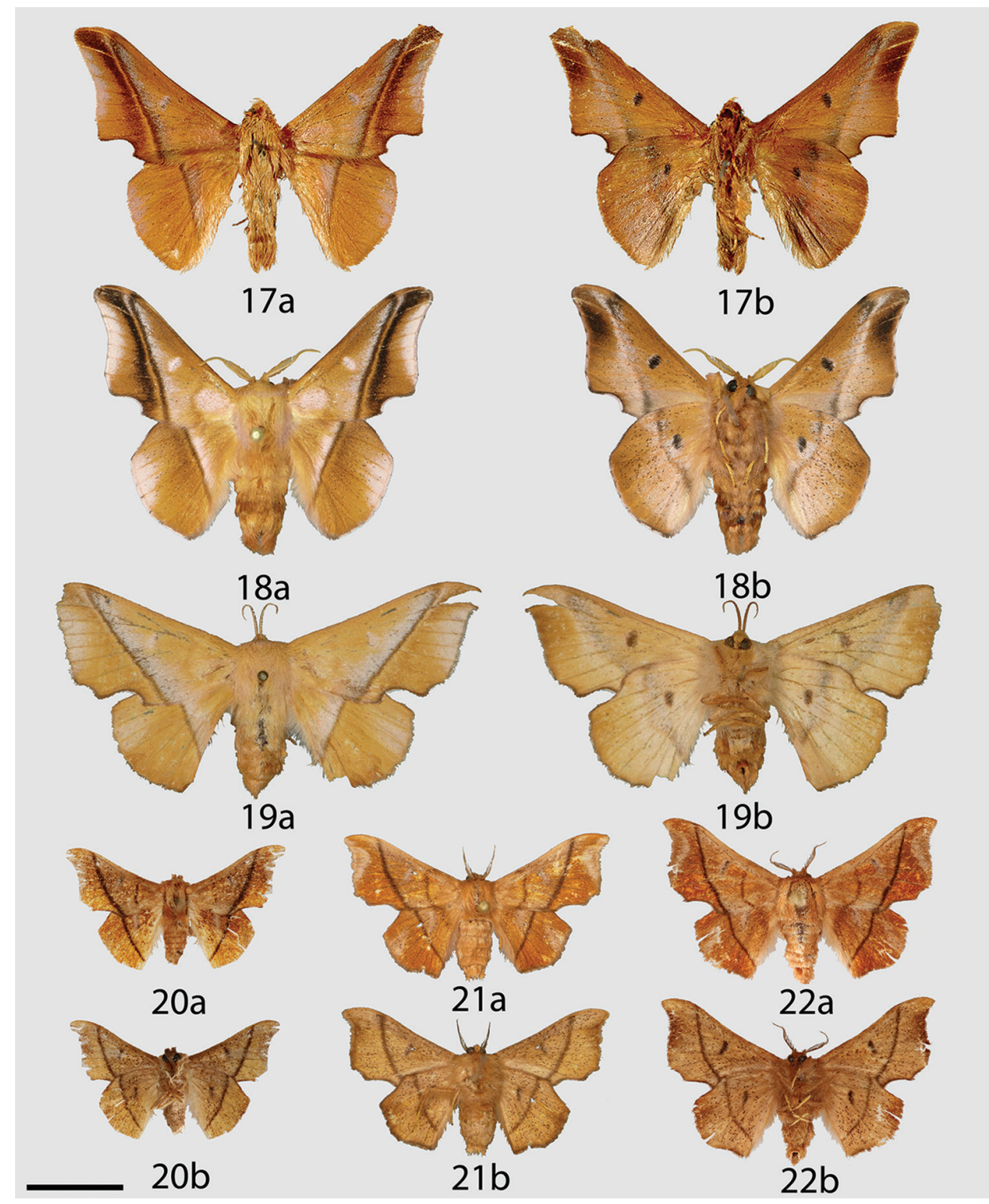

Figures 17-22. Reinmara adults, a dorsal b ventral. 17 R. minasa Holotype $\widehat{\partial}$, Brazil, Minas Gerais, Passa Quatro (MNHU) 18 R. minasa Ô, Brazil, São Paulo, São José do Barreiro, Bocaina, $1539 \mathrm{~m}$ (CGCM) 19 R. minasa + , Brazil, São Paulo, Santo Antônio do Pinhal, Eugênio Lefèvre, 1200 m (MZSP) 20 R. ignea Paratype $\hat{O}$, Brazil, Santa Catarina, Rio Vermelho, $968 \mathrm{~m}$ (ISEZ) 21 R. ignea Holotype $q$, Brazil, São Bento do Sul, Rio Natal, 550 m (DZUP) 22 R. ignea Paratype $\odot$, Brazil, Rio de Janeiro, Nova Friburgo, $1100 \mathrm{~m}$ (USNM). Scale bar: $1 \mathrm{~cm}$.

Leop. Bulhoes [Leopoldo de Bulhóes]: XI.1935, III.1936, ex. coll. R. Spitz, H.R.P[earson] genitalia prep. 4184 [lost], NHMUK010354557, 010354558 (2 \%, NHMUK); XII.1936, ex. coll. R. Spitz, HRP No. 1462 (1 §̂, MNRJ). Distrito Federal: 1 ô, Brasília: 

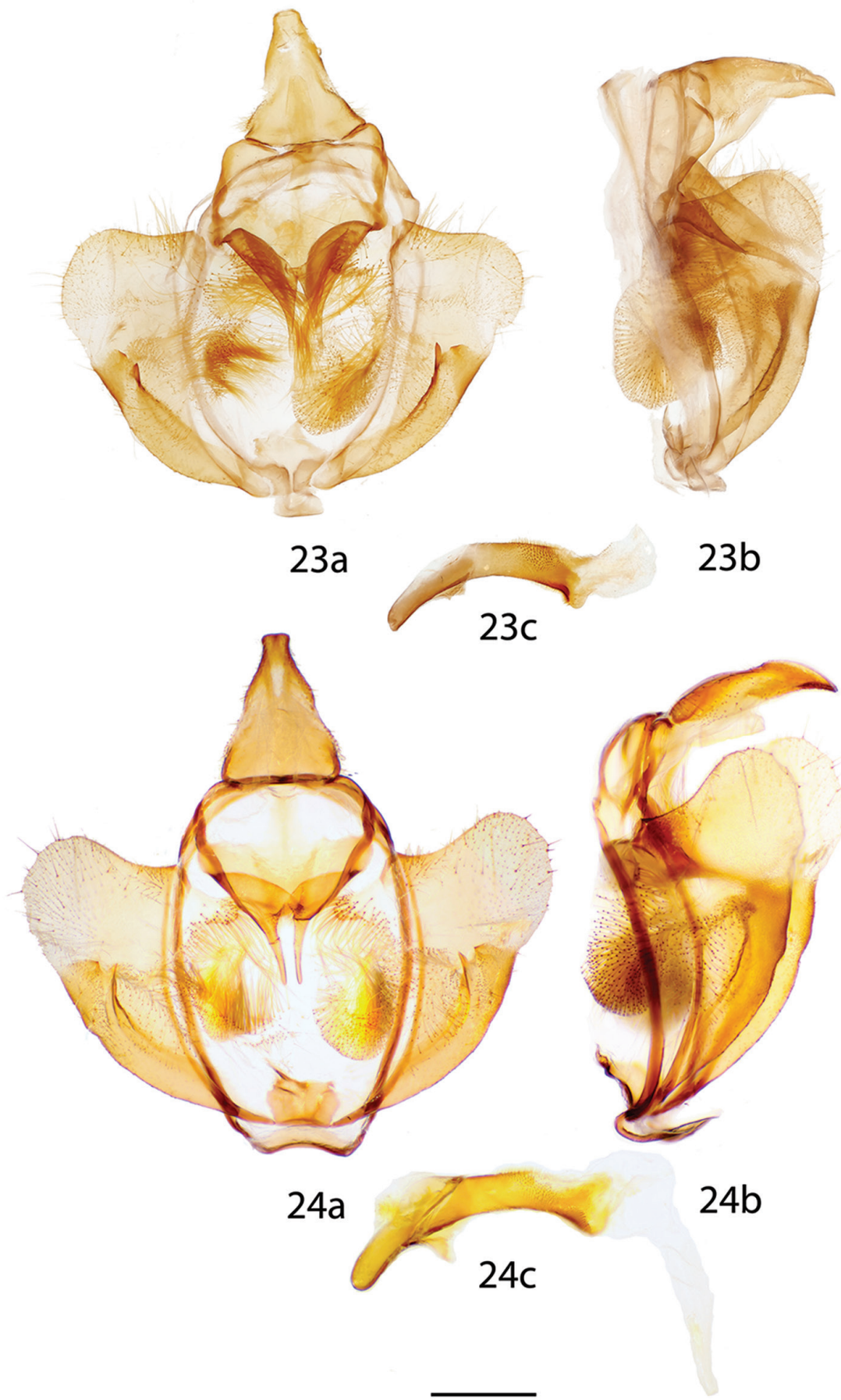

Figures 23, 24. Reinmara male genitalia, a ventral b lateral c phallus lateral. 23 R. enthona, Suriname, Moengo, Boven Cottica River, St Laurent diss.: 10-25-15:2 (CUIC). 24 R atlantica Holotype, Brazil, Espírito Santo, Linhares, 40 m, St Laurent diss.: 11-1-16:6 (DZUP). Scale bar: $1 \mathrm{~mm}$. 


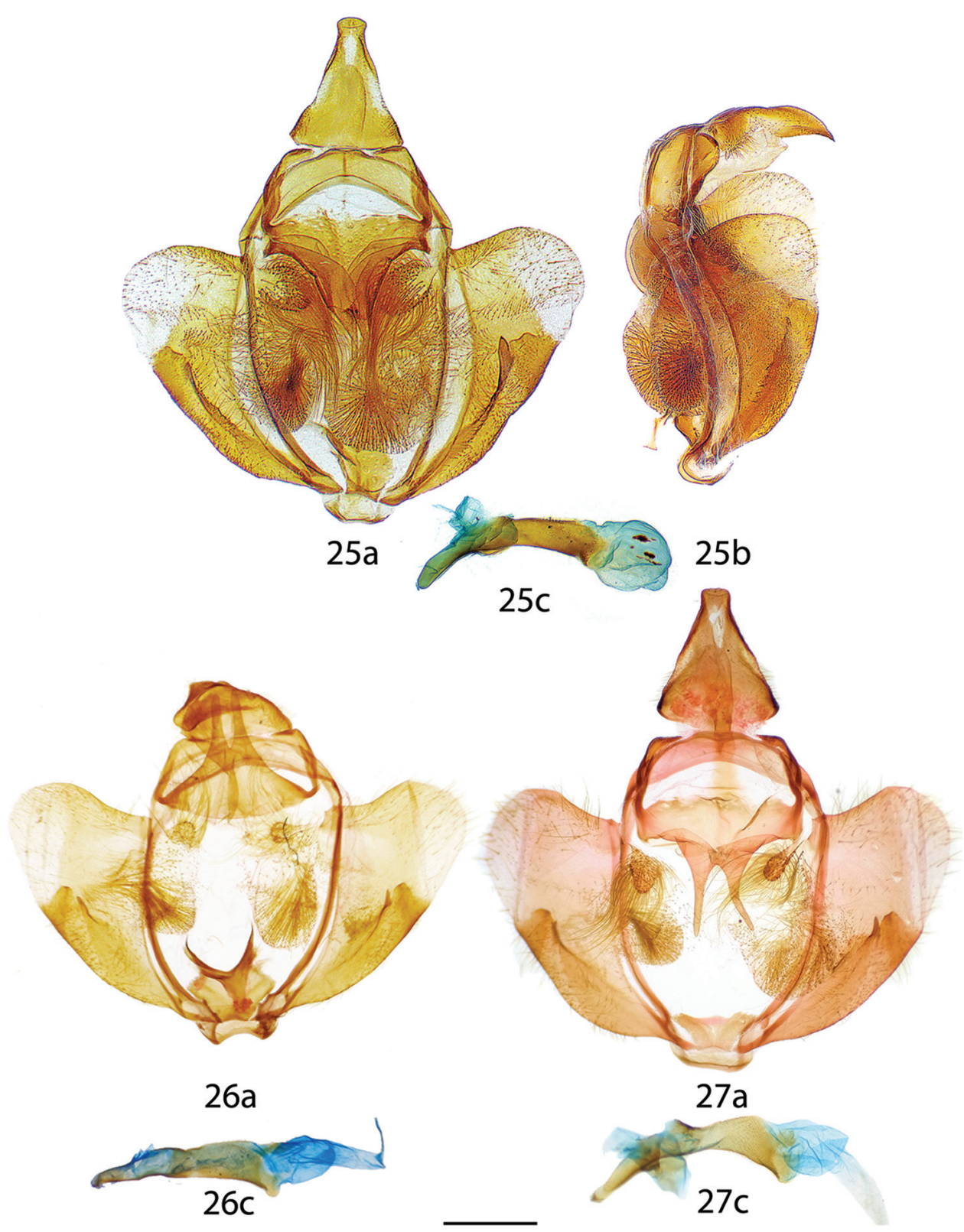

Figures 25-27. Reinmara male genitalia, a ventral b lateral $\mathbf{c}$ phallus lateral. $25 \mathrm{R}$. andensis Holotype, Bolivia, N. Yungas, 1000-1800 m, D. Herbin genitalia prep. H. 1134 (MNHN) 26 R. occidentalis Holotype, Ecuador, El Oro, $10 \mathrm{~km} \mathrm{NW}$ of Piñas, $750 \mathrm{~m}$, genitalia prep. 29.218 [phallus flipped horizontally, oriented somewhat dorsally] (MWM) 27 R. occidentalis Paratype, Ecuador, road Piñas to Saracay, 800 m, genitalia prep. 30.813 [phallus flipped horizontally] (MWM). Scale bar: $1 \mathrm{~mm}$. 


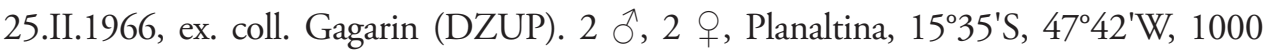
m: 11.XI.1976, 31.III.1977, 9.III.1978, 4.IV.1978, V.O. Becker leg., Coll. EMBRAPACPAC No. 2425, 4940, 6812, 6879 (CPAC). Mato Grosso: 1 đ̊, 60 km south of Poconé, Pantanal, 100 m: 22.V.1998, V.O. Becker leg., ex. Coll. Becker 116547, St Laurent diss.: 11-1-16:2 (USNM). BOLIVIA: Santa Cruz: 1 ô, Aguas Calientes [Roboré]: Travassos, Barros \& Albuquerque leg. (CEIOC).

Diagnosis. Reinmara wolfei is characterized by the small size, sandy, tan brown coloration, only very faint to absent paler shading medially, and a faint or absent discal mark on the hindwing ventrum. The phallus of $R$. wolfei is the shortest and broadest of the genus. The female genitalia are not overly distinct from those of $R$. enthona.

Description. Male. Head: As for genus, coloration brown, antenna coloration brown. Thorax: Coloration lighter brown than that of head. Legs: Coloration as for thorax. Forewing dorsum: Forewing length: $15-17 \mathrm{~mm}$, avg.: $16.3 \mathrm{~mm}$, wingspan: 30-36 mm, $\mathrm{n}=4$. Triangular, outer margin concave, tornus weakly notched. Ground color sandy brown. Ante- and medial areas concolorous, submarginal area above tornus slightly darker brown than remainder of wing in fresh specimens, pale suffusion present on inner side of postmedial line near costa. Antemedial line faint brown, wavy, postmedial line slightly curved, usually thick, black. Discal mark weakly represented by pale splotch with darkened region centrally. Fringe coloration as for remainder of wing or slightly darker. Forewing ventrum: Similar to dorsum but pale suffusions most absent except near apex. Antemedial line absent, postmedial line reduced to wavy traces, discal mark more prominent, darker than on forewing dorsum. Hindwing dorsum: Notch on anterior margin weak, patterning as for forewing dorsum, but antemedial line absent, discal mark and postmedial line weakly defined. Hindwing ventrum: Following same pattern as forewing ventrum. Abdomen: Coloration as for thorax. Genitalia: (Fig. 28) n= 4. Typical of genus, differing in the relatively triangular shape of the uncus, more elongated gnathos mesal extensions with particularly elongated fingerlike tips that are usually slightly bent, sacculus fold with large tooth-like extensions, phallus short, blunt, broad, covered in fine setae. Female. Head: As for male but slightly broader; antenna dentate with very small pectinations along entire length of flagellum. Thorax: As for male. Legs: As for male. Forewing dorsum: Forewing length: $15-19 \mathrm{~mm}$, avg.: $17.3 \mathrm{~mm}$, wingspan: $33-35 \mathrm{~mm}, \mathrm{n}=4$. As for male but much broader, margin convex except for just below apex; tornus strongly notched. Coloration and patterning as for male but discal mark almost entirely absent. Forewing ventrum: Similar to dorsum but more homogenously brown overall due to absence of well-defined ante- and medial areas. Antemedial line absent, postmedial line reduced to outwardly curved traces, discal mark more prominent, discal mark darker than on forewing dorsum. Hindwing dorsum: Similar to forewing dorsum, but notch present on anterior margin, patterning as for forewing dorsum, but antemedial line absent, discal mark and postmedial line usually weakly defined. Hindwing ventrum: Following same pattern as forewing ventrum. Abdomen: Similar to that of males but more robust overall. Genitalia: (Fig. 32) n=1. Stout, robust; tergite VIII forms elongated, posteriorly directed shortened tongue-like overhang, VIII heavily sclerotized laterally 

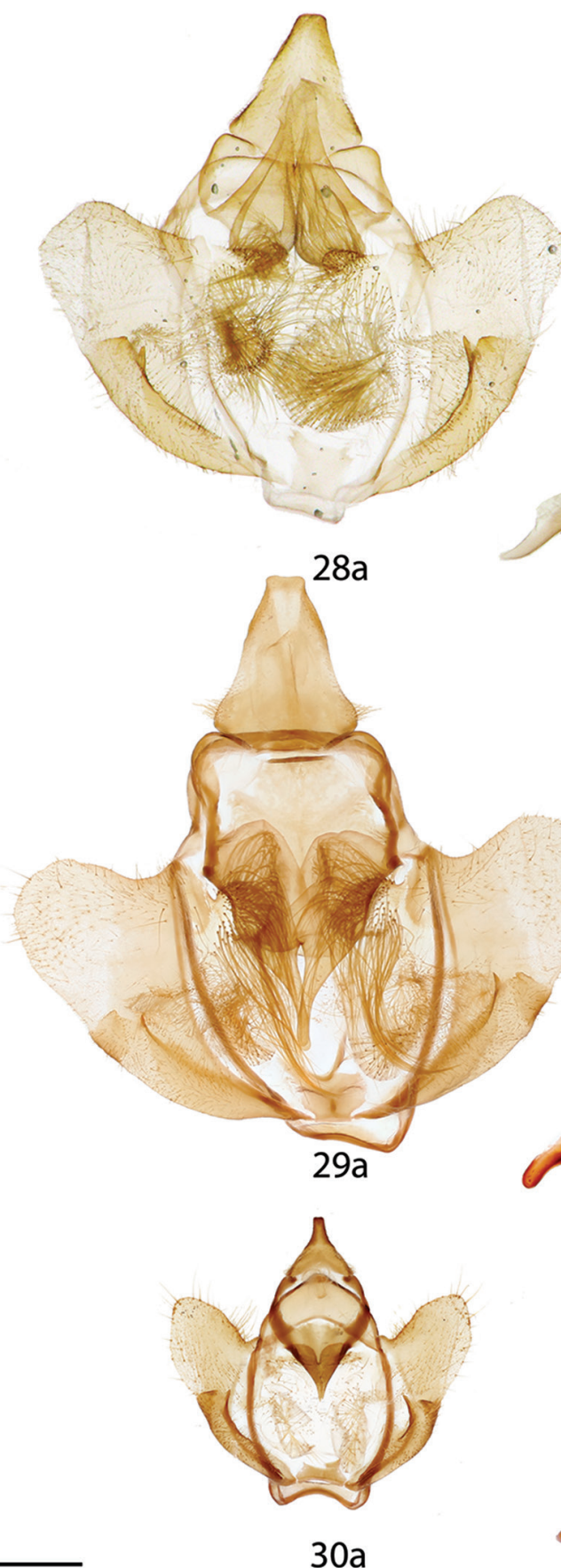

$28 a$

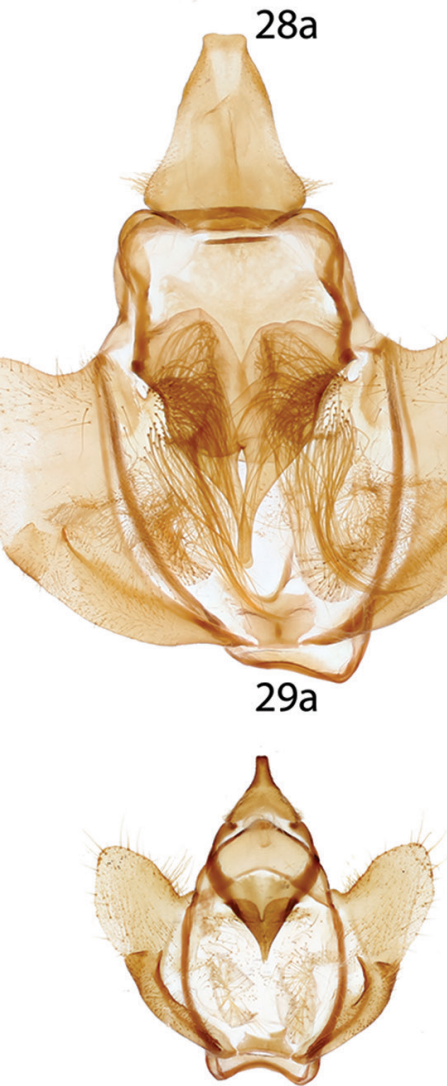

$30 a$

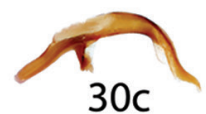

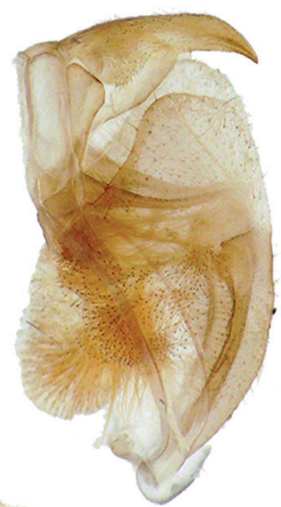

$28 b$

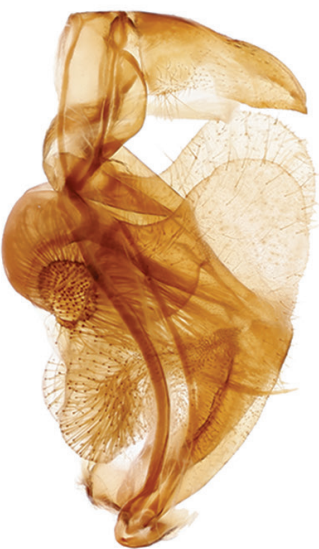

$29 c \quad 29 b$

Figures 28-30. Reinmara male genitalia, a ventral b lateral c phallus lateral. 28 R. wolfei, Brazil, Distrito Federal, Planaltina, 1000 m, C. Mielke genitalia prep. 6.812 (CPAC) 29 R. minasa, Brazil, Espírito Santo, St Laurent diss.: 5-15-16:1 (CUIC) 30 R. ignea Paratype, Brazil, Santa Catarina, São Bento do Sul, Rio Vermelho, 968 m, St Laurent diss.: 5-6-16:1 (ISEZ). Scale bar: $1 \mathrm{~mm}$. 
forming curving plate below papillae anales. Apophyses anteriores roughly half-length of apophyses posteriores. Lamella ante- and postvaginalis converge as a wide, bowl-like structure covered in setae. Ductus bursae short, narrow. Corpus bursae rather small in comparison to robust, heavily sclerotized remainder of genitalia, balloon-like. Papillae anales broad, apical pronounced, covered in long, fine setae.

Distribution (Fig. 36). Reinmara wolfei is endemic to the Cerrado of central South America, with few records from Brazil in the states of Maranhão, Goiás, and Distrito Federal. We also report a specimen from the wet Pantanal in Brazil, Mato Grosso. A specimen from Cerrado habitat in Bolivia, Santa Cruz, is reported here as well.

Remarks. We figure and describe the female of this species for the first time, as well as the first Bolivian record. Until now, this species was known only from the male holotype from Maranhão, Brazil. We note some minor external differences between the specimens from drier Cerrado and that of the wet Pantanal, such as the slightly smaller size and brighter coloration in the Pantanal specimen (Fig. 15), but genitalia of this specimen are not noticeably different from those of typical $R$. wolfei.

\section{Reinmara minasa Schaus, 1928}

Figs 17-19, 29, 33, 36

Reinmara minasa Schaus, 1928: 655, fig. đ̋ 88b

Reinmara minasa; Gaede 1931

Reinmara minasa; Becker 1996

Reinmara minasa; Herbin and Mielke, 2014

Type material. Holotype, $\widehat{\jmath}$. BRAZIL: Minas Gerais: Passa Quatro, Sul de Minas [SE of Minas Gerais], S.O. Brasilien, Jos. Zikán [leg.]/ [Holo]Typus/ No. [illegible] 6, 19-I-22/ Reinmara minasa Schaus type/ (MNHU, examined). Type locality: Brazil, Minas Gerais, Passa Quatro.

Additional specimens examined. (39 §, 2 total) BRAZIL: Espírito Santo: $1 \precsim$, No additional data, St Laurent diss.: 5-15-16:1 (CUIC). Minas Gerais: $1 \hat{\jmath}$, Itamonte, Vargem Grande, 1600 m: 17.II.2010, [O.] Mielke \& Casagrande leg. (DZUP). 1 ふै, Alto Caparaó, Tronqueira, 20²4'38"S, 4150'07"W, 1994 m: 10.XI.2012, B. Vincent

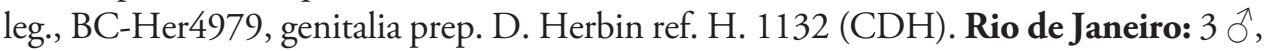
[Itatiaia], Pico de Itatiaia: 28.III-1.IV.1958, H.B.D. Kettlewell [leg.], B.M. 1958-273 (NHMUK). 3 ふै, Itatiaia, L. 41, 1300 m: 3-8.II.1951, Trav[assos] \& Albuquerque [leg.] (NHMUK, 2 đ); 6-10.XII.1950, 270, USNM-Mimal: 2422, St Laurent diss.: 11 -

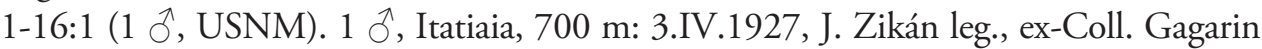
(DZUP). 1 đે, Itatiaia, 1200 m: II.1960, H. Ebert leg. (ZSM). 2 đ, Parque Nacional do Itatiaia, Lago Azul, 800 m: 19.III.1955, G. \& H. Pearson leg., HRP No. 784, USNMMimal: 2381 (USNM); 14-17.IV.1956, Pearson \& R. Barros [leg.], HRP No. 776, USNM-Mimal: 2382 (USNM). 1 đ̃, [Itatiaia], Campo Bello [Campo Belo]: Zikán leg., USNM-Mimal: 1788 (USNM). Sáo Paulo: 7 đ̃, 1 ๆ, Campos do Jordão [Santo An- 


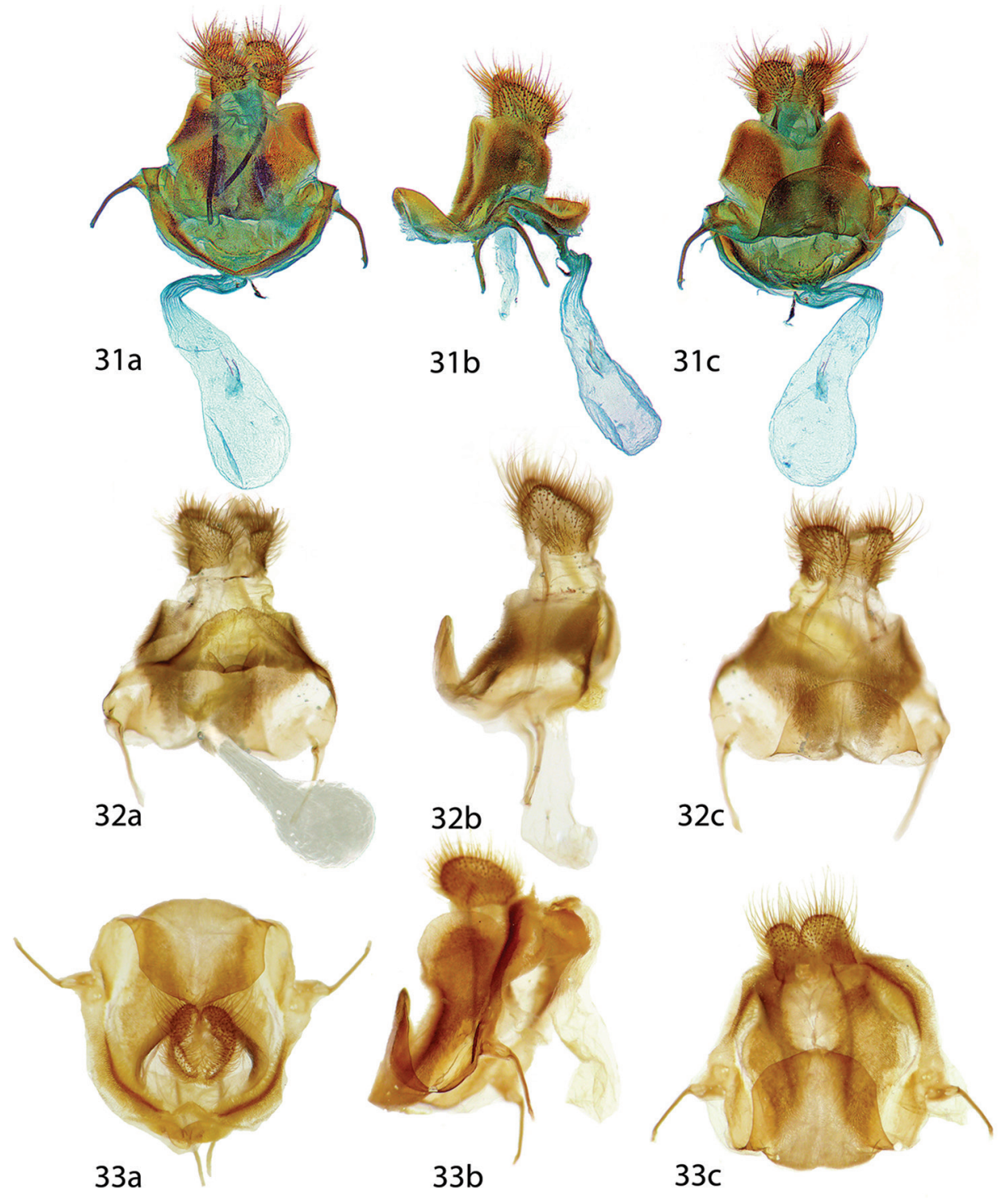

Figures 3 I-33. Reinmara female genitalia, a ventral b lateral c dorsal. $3 \mathbf{I}$ R. enthona, French Guiana, Kaw Rd., PK 37.5 + 2, 200 m, D. Herbin genitalia prep. H. 1103 (CDH) 32 R. wolfei, Brazil, Distrito Federal, Planaltina, 1000 m, C. Mielke genitalia prep. 6.879 (CPAC) 33 R. minasa, Brazil, São Paulo, Santo Antônio do Pinhal, Eugênio Lefevre, 1200 m, C. Mielke genitalia prep. 28.071 (MZSP). Scale bar: $1 \mathrm{~mm}$.

tônio do Pinhal], Eugênio Lefevre, 1200 m: 13-20.XI.1952, L. Travassos Filho, D’Almeida, \& Pd. Pereira [leg.]; 15-20.XII.1952, L. Travassos Filho \& D’Almeida [leg.]; 14-17.I.1953, L. Travassos Filho \& S. Medeiros [leg.]; 13-15.II.1953, L. Travassos 
Filho \& L. Travassos [leg.]; 22.III.1963, L. Travassos Filho, J. Guimaráes, E. Rabello, \& A. Barroso [leg.], MSZP Nos. 28065-28071, q genitalia prep. MZSP 28071 (6 つૈ, 1 ㅇ, MZSP); 16.XII.1952, D’Almeida \& L. Travassos F. leg., Ex-coll. D’Almeida (1 ô, DZUP). 1 đ̂, Eugênio Lefèvre [train station, Santo Antônio do Pinhal], 1162 m: ex. Coll. Gagarin (DZUP). 2 ๙ , Campos do Jordão, Umuarama, 1800 m: 3-15.II.1937 [DZ 33.014], 8-15.III.1937, Gagarin leg., ex. Coll. Gagarin (DZUP). 6 ô, São José do Bar-

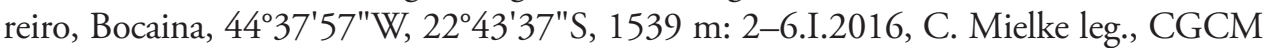
31.240, CGCM 31.263, CGCM 31.274, CGCM 31.285, CGCM 31.310, CGCM

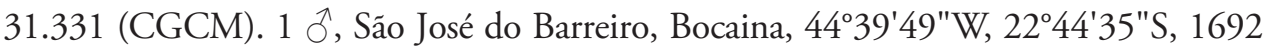
m: 9-10.X.2015, C. Mielke leg., CGCM 30.813 (CGCM). 1 đે, Termas de Lindóia [Águas de Lindóia]: 27.I.1950, N. \& R. D’Almeida leg., ex. Coll. D’Almeida (DZUP). $1 \hat{O}$, Anhembi, Faz. Bar. Rico: 1.III.1960, LTF A. Barroso (MZSP). 1 ㅇ, Termas de Lindoia [recte Aguas de Lindóia]: 10.II.1950, D’Almeida leg. (MNRJ). Paraná: 3 O, [Piraquara], Banhados, railroad from Curitiba to Paranaguá, 800 m: 11.II.1972, E.G., I. \& E.A. Munroe [leg.], St Laurent diss.: 5-8-16:2 (CNC). 2 đ̂, Tibagi, Guartelá, 975 m: 18.I.2012, 3.III.2012, C. Mielke leg. (CDH). Santa Catarina: 1 J, Serra do Paneláo, Urubici, 2753.989'S, 49³5.156'W, 1250 m: 26-27.II.2007 (CDH).

Diagnosis. This unique species of Reinmara can be recognized by the black suffusion along the entire length of the forewing postmedial line in males, which reaches the apex, darkening it. In both males and females there is a well-defined, narrow, pale pink suffusion along the postmedial line (outside of the black suffusion of the males, which is absent in females), leaving the remainder of the medial area mostly clear of pale pink suffusions. The male genitalia is recognizable by the uniformly narrow phallus with a usually distinctly backward splayed distal ventral tip, the uncus is quite broad. Among the species for which the female is known, $R$. minasa female genitalia is characterized by the largest dorsal projection of the tergite VIII as well as by the robustness of the lateral plates below the papillae anales.

Description. Male. Head: As for genus, coloration light brown. Thorax: Coloration as for head but with pale pink scales present on prothoracic collar and base of wings. Legs: Coloration as for thorax, but with additional, dark petiolate scales sparsely scattered amongst vestiture, tarsus yellower. Forewing dorsum: Forewing length: 16.5-21.0 $\mathrm{mm}$, avg.: $18.1 \mathrm{~mm}$, wingspan: $33.0-42.5 \mathrm{~mm}, \mathrm{n}=9$. Acutely triangular, narrow, outer margin concave; tornus deeply notched nearly until postmedial line, apex somewhat falcate. Ground color brown, very sparsely scattered with dark brown, tiny petiolate scales. Antemedial area with pale pink hue, medial area displaying narrow strip of ground color between pink hue of antemedial area and inner pink suffusion of postmedial line, submarginal area darker brown than medial area with pale gray lunule-like marking on margin and strong, black suffusion on outer edge of postmedial line, black suffusion becoming widest and more diffuse near tornus, extending along entire postmedial line to apex. Antemedial line hardly distinguishable but present as outwardly bent brown wave, postmedial line nearly straight. Discal mark variable from pale pink splotch with little to no black scales in center to almost entirely covered by black scales. Fringe coloration nearly white with darker scales at wing vein intersections. Forewing ventrum: As for genus but pale pink 
scales along postmedial line broadly scattered, postmedial line as on dorsum straight, but only fainter, black suffusion replaces lunule-like submarginal shape of dorsum. Hindwing dorsum: Notch on anterior margin weak, patterning as for forewing dorsum, but antemedial line absent, discal mark nearly always absent, pale suffusion submarginally similar to forewing lunule-like area. Hindwing ventrum: Following same pattern as forewing ventrum but postmedial line wavier, discal mark present, pale pink suffusion widely expanded throughout medial and submarginal areas. Abdomen: As for genus. Genitalia: (Fig. 29) $\mathrm{n}=4$. Typical of genus, differing in the relative shortness and (usual) broadness of uncus, generally more robust gnathos mesal extensions with particularly elongated fingerlike tips, phallus narrow and smoothly curved, somewhat boomerang shaped, tip of phallus splayed open with ventral edge forming backwardly angled lip. Vesica bulbous with distally extended narrower portion. Female. Head: As for male, but antenna dentate with very small pectinations along entire length of flagellum. Thorax: As for male. Legs: As for male. Forewing dorsum: Forewing length: $21 \mathrm{~mm}$, wingspan: $43 \mathrm{~mm}, \mathrm{n}=1$. As for male but much broader, margin nearly straight. Coloration and patterning as for male except outer black suffusion along postmedial line absent. Forewing ventrum: Similar to dorsum but lighter, homogenous brown without distinctly different areas of wing except for darker brown region submarginally. Antemedial line absent, postmedial line very faint, discal mark more prominent, darker than on forewing dorsum. Hindwing dorsum: Similar to forewing dorsum, notch present on anterior margin, patterning as for forewing dorsum, but antemedial line and discal mark absent. Hindwing ventrum: Following same pattern as forewing ventrum. Abdomen: Similar to that of males but more robust overall. Genitalia: (Fig. 33) $\mathrm{n}=1$. Very stout, robust; tergite of VIII forms elongated, posteriorly directed tongue-like overhang, VIII heavily sclerotized laterally forming curving plate encircling the papillae anales, curved plate weakly curling backward near papillae anales. Apophyses anteriores roughly half-length of apophyses posteriores. Lamella ante- and postvaginalis converge as a wide, bowl-like structure covered in setae. Ductus bursae short, narrow. Corpus bursae rather small in comparison to robust, heavily sclerotized remainder of genitalia, baglike. Papillae anales broad, rounded, covered in long, fine setae.

Distribution (Fig. 36). Reinmara minasa is endemic to southeastern to south Brazil, and is found in mountainous regions of the states of Espírito Santo, Minas Gerais, Rio de Janeiro, São Paulo, Paraná, and Santa Catarina, at elevations ranging from 700-2000 m.

Remarks. Until now, very little has been reported on this species. We figure and describe the female of $R$. minasa for the first time.

\section{Reinmara ignea sp. $\mathbf{n}$.}

http://zoobank.org/60EF2888-A2B1-43E5-AA6D-3D40BAF74821

Figs 20-22, 30, 34-36

Type material. Holotype, +. BRAZIL: Santa Catarina: BRAZIL - SC, São Bento do Sul, Rio Natal, 550 m., (no date). I. Rank leg./ 20.982 Col. C. Mielke [dissec- 
tion number equivalent]/ HOLOTYPE female Reinmara ignea St Laurent, Herbin, C. Mielke, 2017 [handwritten red label]/ (DZUP). Type locality: Brazil: Santa Catarina: São Bento do Sul, Rio Natal.

Paratypes. ( $1 \hat{\sigma}, 1$ total) BRAZIL: Santa Catarina: $1 \hat{\sigma}$, São Bento do Sul, Rio Vermelho, 968 m: 26.II.1973, A. \& J. Razowski leg., St Laurent diss.: 5-6-16:1 (ISEZ). Rio de Janeiro: 1 q, Nova Friburgo, 1100 m: 21.I.1998, V.O. Becker leg., ex. Coll. Becker 112810, St Laurent diss.: 2-29-16:1 (USNM).

Diagnosis. This unique species cannot be confused with any other Mimallonidae. Reinmara ignea is the smallest species of Reinmara, bearing little outward resemblance to others of the genus. The tiny size, sharply acute and falcate forewings, thick postmedial and antemedial lines, narrow and curving phallus, are just the most immediately recognizable characters enabling the identification of this new species. We also note that this is the only species of Reinmara for which the female has bipectinate antennae like the male (albeit smaller overall), not dentate as in other female Reinmara.

Description. Male. Head: As for genus but coloration pale beige, antenna coloration pale brown due to scaling, but much darker brown beneath scales, vestigial proboscis not visible. Thorax: Coloration as for head. Legs: Coloration as for thorax, vestiture homogenously colored. Forewing dorsum: Forewing length: $12 \mathrm{~mm}$, wingspan: $24 \mathrm{~mm}, \mathrm{n}=1$. Triangular, outer margin concave; tornus weakly notched, apex falcate. Ground color light orange-brown, speckling of tiny petiolate scales. Ante- and medial areas concolorous, darker brown than submarginal area, submarginal area much lighter orange-brown, appearing nearly yellow, faint pale lunule-like marking along margin below apex. Antemedial line defined, dark brown, slightly outwardly bowed, postmedial line also dark brown, slightly wider than antemedial line, barely curved. Discal mark as pale splotch, with obscured, darker central region. Fringe not well preserved. Forewing ventrum: Compared to forewing dorsum, more subdued tan brown, homogenous across all areas of wing, antemedial line absent, postmedial line as for dorsum, petiolate scaling heavier, especially antemedially, discal mark dark brown streak. Hindwing dorsum: Shape more rounded than forewing, outer margin convex except straight anterior margin, patterning as for forewing dorsum but both ante- and medial areas lighter, more similar to submarginal area in coloration, antemedial line absent, postmedial line as for forewing dorsum, well defined, discal mark present but weakly as pale streak. Hindwing ventrum: Following same pattern as forewing ventrum. Abdomen: As for genus. Genitalia: (Fig. 30) n=1. Rather typical of genus, differing in smaller setae-filled sacks in diaphragm, which contain fewer setae, a more triangular, truncated uncus, gnathos round rather than rectangular, with triangular, dual mesal extensions that are fused together, extensions barely separated distally into short paired, fingerlike tips, sacculus fold particularly well developed and more symmetrical, phallus strongly curved, distally flattened and bent. Female. Head: As for male but slightly darker in color; antenna bipectinate and similar to that of male, but slightly smaller overall. Thorax: As for male but darker brown. Legs: As for male but darker brown overall with lighter yellow tarsus, tibial spurs more heavily clothed in scales. Forewing dorsum: Forewing length: $12-16 \mathrm{~mm}$, avg.: $14 \mathrm{~mm}$, wingspan: 

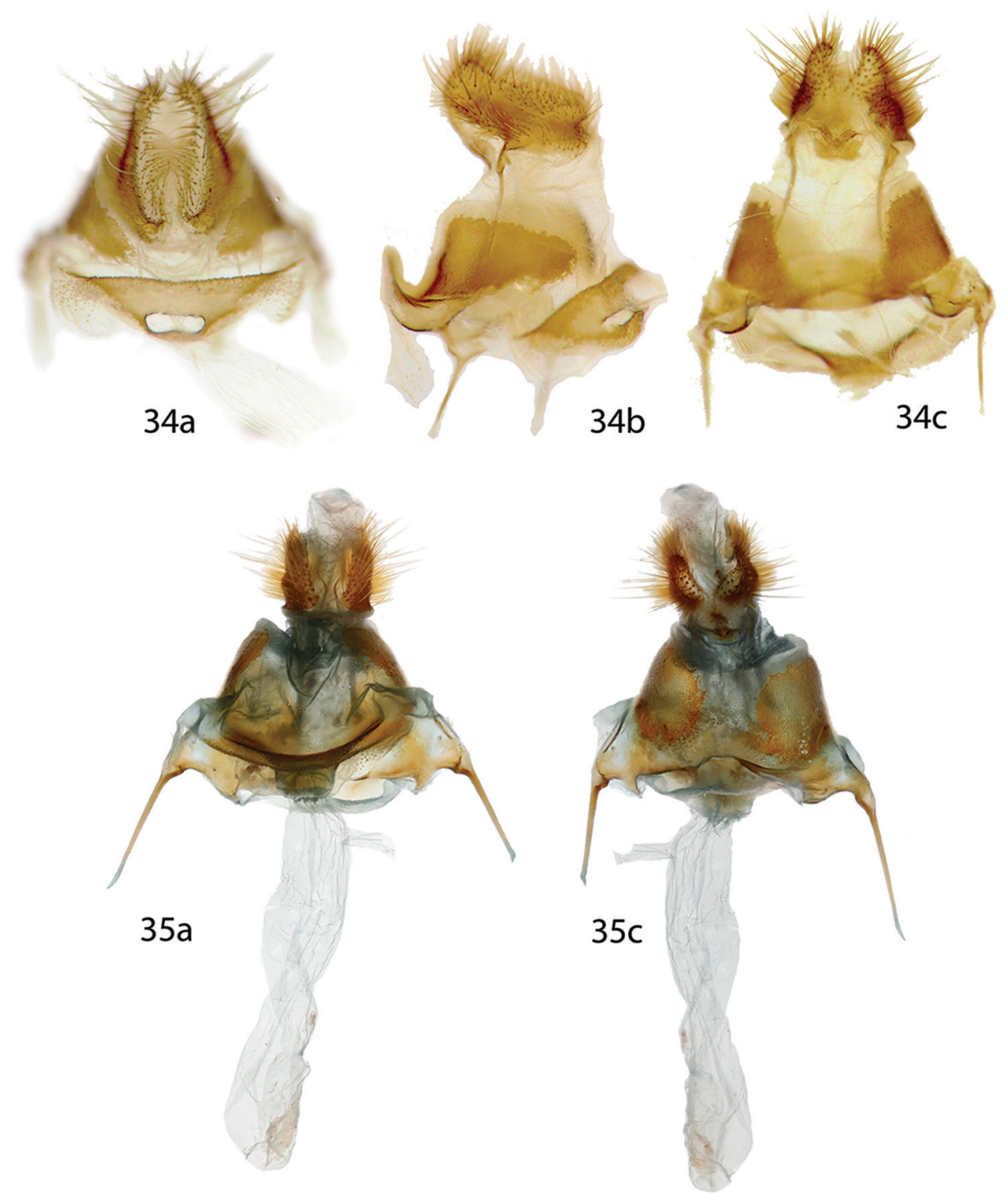

Figures 34, 35. Reinmara ignea female genitalia, a ventral b lateral c dorsal. 34 Holotype ${ }^{2}$, Brazil, São Bento do Sul, Rio Natal, 550 m, C. Mielke genitalia prep. 20.982 (DZUP) 35 Paratype , Brazil, Rio de Janeiro, Nova Friburgo, 1100 m, St Laurent diss.: 2-29-16:1 (USNM). Note: different orientation of two preparations obfuscates their actual similarity, in Fig. 34 a the lamella ante- and postvaginalis are pressed downward. Scale bar: $1 \mathrm{~mm}$.

27-31 mm, $\mathrm{n}=2$. Shape essentially as for male but tornus slightly notched. Maculation as for male, but coloration darker orange-brown to red brown submarginally. Submarginal area proportionally wider. Forewing ventrum: Compared to forewing 
dorsum, more subdued tan brown, homogenous across all areas of wing, antemedial line absent, postmedial line as for dorsum, petiolate scaling heavier, especially antemedially, discal mark dark brown streak. Hindwing dorsum: As for male but medial and submarginal areas more distinctly bicolored (similar to forewing dorsum). Hindwing ventrum: Following same pattern as forewing ventrum. Frenulum as multiple bristles. Abdomen: Similar to that of male but more robust overall. Genitalia: (Figs 34, 35) $n=2$. Tergite of VIII forming short, thin posteriorly directed extension, VIII sclerotized laterally forming curving plate, but not extended to encircle papillae anales. Apophyses anteriores roughly equal in length apophyses posteriores. Lamella ante- and postvaginalis converge as a wide, bowl-like structure. Ductus bursae short, rectangular. Corpus bursae elongate, tubular. Papillae anales somewhat narrow, covered in long, fine setae.

Distribution (Fig. 36). Reinmara ignea is so far known only from two nearby localities in São Bento do Sul, Santa Catarina, and a third locality in Rio de Janeiro State, Brazil. These two areas are separated by about $815 \mathrm{~km}$ and both fall in the mountainous region of the Brazilian Atlantic Forest.

Etymology. This new species is named for its fiery (ignea Latin) coloration, reminiscent of burning embers.

Remarks. Until the first author dissected the single male of this new species, proper generic placement was not clear to us, and we had originally considered $R$. ignea as belonging to an undescribed genus. Despite the outward uniqueness of both sexes, the genitalia of both sexes display characters fundamental to the diagnosis of the genus Reinmara. In the male, the structure and shape of the valves, the broad, mesally fused but distally separated gnathos, and balloon-like setae-filled sacs extending inward into the body cavity from the diaphragm are all typical of Reinmara, the gnathos character precluding $R$. ignea from placement in the related Trogoptera. Female genitalia are similar to those of other species of Reinmara, but the tergite VIII extension is particularly weakly sclerotized and thin (though present). We also note that this is the only species in the genus for which the female antennae are similar (bipectinate) to those of the male, just smaller, as in most mimallonid genera, not dentate as in the females of $R$. enthona, $R$. wolfei, and $R$. minasa.

We note minor difference in maculation of the two female specimens of $R$. ignea (compare Figs 21 and 22), as well as in their genitalia, but due to the otherwise close similarity (in comparison with other species in the genus) and the apparent rarity of this species, we include both specimens in the type species.

This species and $R$. atlantica may very well be of conservation concern due to the present state of fragmentation of the biome to which they are endemic (Ribeiro et al. 2009). The lack of specimens of $R$. ignea from this otherwise relatively well-collected region suggests that it may be rare and/or only weakly attracted to light. It is notable that most specimens of $R$. ignea are female. The opposite is true for other Reinmara where both sexes are known, where males far outnumber collected females.

Two additional female specimens were located in the collection of Ivo Rank, collector of the holotype, but they are not included in the type series. 


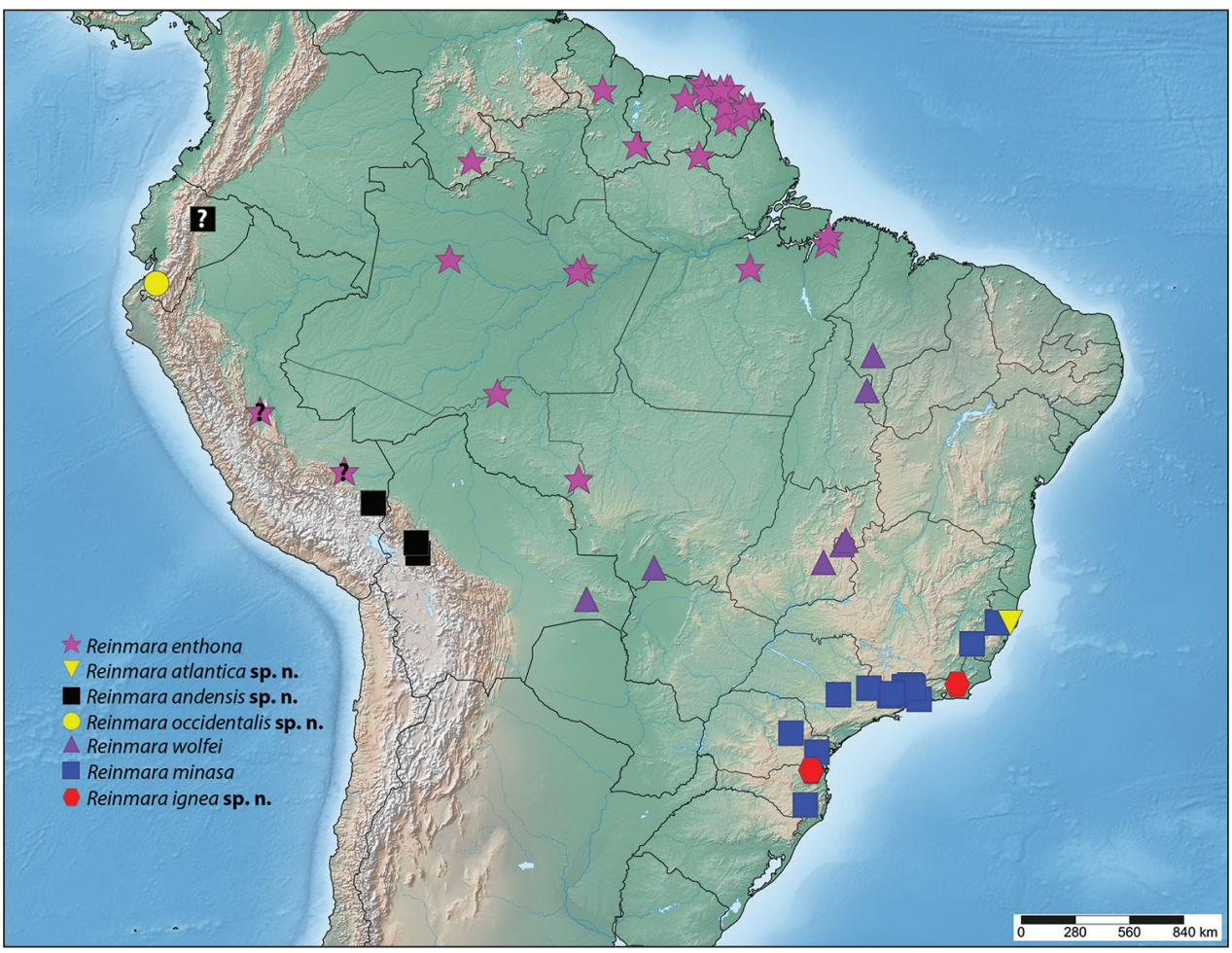

Figure 36. Known distribution of Reinmara.

\section{Acknowledgements}

The following individuals and their respective institutions were vital to this research in enabling us to examine and study Reinmara material: Courtney Richenbacher and David Grimaldi (AMNH), Christian Schmidt (CNC), Philippe Collet (CPC), Mirna Casagrande (DZUP), Lukasz Przybylowicz (ISEZ), Wolfram Mey (MNHU), Joël Minet and Rodolphe Rougerie (MNHN), Thomas Witt, Alexey Prozorov, Thomas Greifenstein, and Harald Sulak (MWM), Alexandre Soares (MNRJ), Marcelo Duarte and Rafael Dell'Erba (MZSP), Alessandro Giusti (NHMUK), Tobias Malm (NHRS), Aline Vieira Miranda (CEIOC), John Brown, Brian Harris, and Robert Robbins (USNM), Vitor Becker (VOB). Stefan Naumann supplied photos of specimens from ZSM. Jason Dombroskie (CUIC) provided access to specimens as well as photography equipment. Several individuals at the MGCL provided assistance on this work, including Lawrence Reeves who photographed the specimen in Figure 15, Kelly Dexter who taught the first author DNA extraction procedures and assisted in the barcoding of Reinmara samples, James Hayden who permitted access to the Lepidoptera collection, and Akito Kawahara who provided laboratory space and materials for performing several portions of this study. Ivo Rank donated the holotype of $R$. ignea to C. Mielke (who will then donate it to DZUP). The journal Antenor permit- 
ted the reuse of the photo of the holotype of $R$. wolfei (Fig. 13). Fernando Maia Silva Dias (Brazil), Jason Dombroskie, and Christian Schmidt each offered helpful corrections and suggestions on the manuscript. Publication of this article was funded by the University of Florida Open Access Publishing Fund.

\section{References}

Adobe (2008) Photoshop CS4: version 11.0.

Barcode of Life [or BOLD or BOLDSYSTEMS] (2013) Advancing species identification and discovery by providing an integrated environment for the assembly and application of DNA barcodes. Barcode of life data systems. http://www.barcodinglife.org or www. boldsystems.org [2/6/2017]

Becker VO (1996) Mimallonidae. In: Atlas of Neotropical Lepidoptera, Checklist. Part 4B. Drepanoidea, Bombycoidea, Sphingoidea. Association for Tropical Lepidoptera \& Scientific Publishers, Gainesville, Florida, 17-19.

Fletcher DS, Nye IWB (1982) Bombycoidea, Castnioidea, Cossoidea, Mimallonoidea, Sesioidea, Sphingoidea, Zygaenoidea. In: Nye IWB (Ed.) The generic names of moths of the world. Trustees of the BMNH, London, $192 \mathrm{pp}$.

Gaede M (1931) Pars 50: Mimallonidae. In: Strand E (Ed.), Lepidopterorum Catalogus. W. Junk, Berlin, 2-19.

Hebert PDN, Cywinska A, Ball SL, deWaard JR (2003) Biological identifications through DNA barcodes. Proceedings of the Royal Society B: Biological Sciences, 270, 313-321. https://doi.org/10.1098/rspb.2002.2218

Herbin D, Mielke C (2014) Preliminary list of Mimallonidae from Feira Nova do Maranhão, Maranhão, northern Brazil with description of some new species. Antenor 1(2): 130-152.

Kimura M (1980) A simple method for estimating evolutionary rate of base substitutions through comparative studies of nucleotide sequences. Journal of molecular Evolution, 16: 111-120. https://doi.org/10.1007/BF01731581

Kristensen NP (2003) 4. Skeleton and muscles: adults. In: Kristensen NP (Ed.) Band 4: Arthropoda, 2 Hälfte: Insecta, Lepidoptera, Moths and Butterflies, Teilband/Part 36, Vol 2: Morphology, Physiology, and Development. Walter de Gruyter, Berlin, Boston, 39-131. https://doi.org/10.1515/9783110893724.39

Lafontaine JD (2004) The moths of North America. Noctuoidea: Noctuidae (part). Noctuinae (part Agrotini). Fasc. 27.1. In: Dominick R, Ferguson D, Franclemont J, Hodges R, Munroe E (Eds) Wedge Entomological Research Foundation, Washington, DC, 385 pp. Piñas Rubio F (2007) Mariposas del Ecuador, Vol. 19. Compania Jesus, Quito, Ecuador. Ribeiro MC, Metzger JP, Martensen AC, Ponzoni FJ, Hirota MM (2009) The Brazilian Atlantic Forest: How much is left, and how is the remaining forest distributed? Implications for conservation. Biological Conservation 142: 1141-1153. https://doi.org/10.1016/j.biocon.2009.02.021

Saitou N, Nei M (1987) The neighbor-joining method: A new method for reconstructing phylogenetic trees. Molecular Biology and Evolution 4: 406-425. 
Schaus W (1905) Descriptions of new South American moths. Proceedings of the United States National Museum 29: 179-345. https://doi.org/10.5479/si.00963801.1420.179

Schaus W (1928) Familie Mimallonidae. In: Seitz A (Ed.) Die Gross Schmetterlinge der Erde. 6. Die amerikanischen Spinner und Schwärmer. A. Kernen, Stuttgart, 635-672.

Stoeckle MY, Hebert PDN (2008) Barcode of Life. Scientific American, 299: 82-88.

Sukumaran J, Knowles LL (2017) Multispecies coalescent delimits structure, not species. Proceedings of the National Academy of Sciences 114(7): 1607-1612. https://doi. org/10.1073/pnas.1607921114

Tamura K, Stecher G, Peterson D, Filipski A, Kumar S (2013) MEGA6: Molecular Evolutionary Genetics Analysis version 6.0. Molecular Biology and Evolution 30(12): 2725-2729. https://doi.org/10.1093/molbev/mst197

Thöny H, Piñas F (2015) Remarks, Corrections, Comments and Additions to Vol. 23 and 25 of the "Mariposas del Ecuador" on the Genus Gonodonta Hübner, 1818. Lepidoptera Research 25(1): 15-21.

Thöny H, Piñas Rubio F (2017) Bemerkungen, Korrekturen, Kommentare und Nachträge zu „Mariposas del Ecuador“ von Pińas Rubio, 2005, Vol. 22 \& 25, Noctuidae, Plusiinae 3. Beitrag zur Heterocera - Fauna von Ecuador (Lepidoptera, Noctuoidae, Noctuidae, Plusiinae). Entomofauna, Zeitschrift Für Entomologie 38(11): 213-232. 